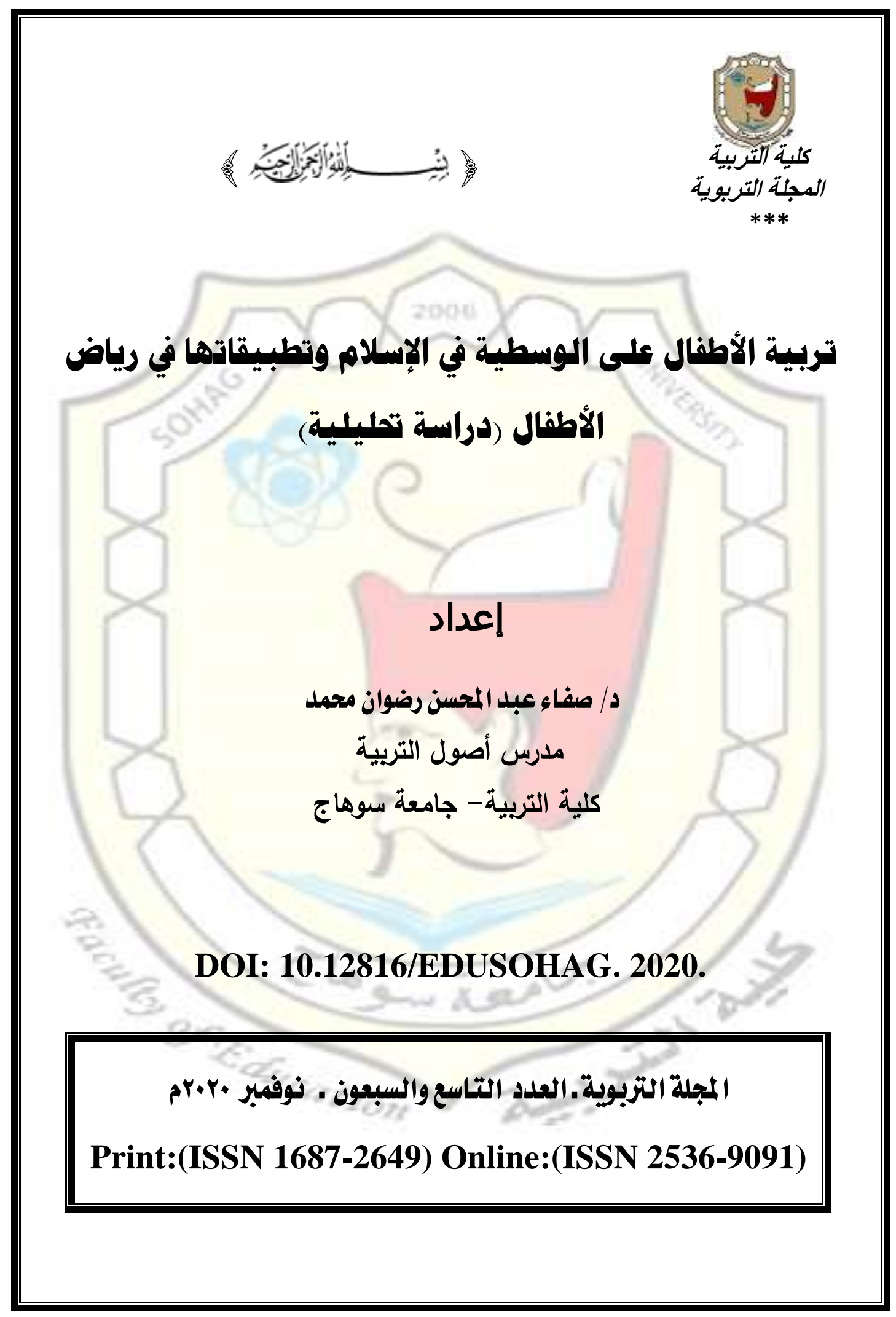


ماخص البحث

هدف البحث الحالي إلى تعرّف المقصود بالوسطية في الإسلام، وأهم خصائصها، والوقوف على دور رياض الأطفال في تربية الطقل على الوسطية، وتعزّف التطبيقات التريوية للوسطية في

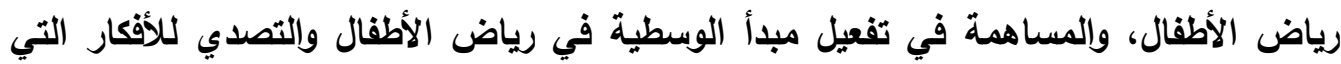
تدعو للانحراف والتطرف.

كما نبعت أهمية البحث من أهمية الموضوع الأي يناقشه؛ حيث إن تحقيق مبدأ الوسطية عند أفراد المجتمع المسلم يعد ضرورة اجتماعية وتربوية لازمة في كل مكان وزمان، وأن تفعيل الوسطية يحقق الاستقرار في المجتمع بأكمله وخاصة في الوقت الحاضر الأي يعاني من افتقاد

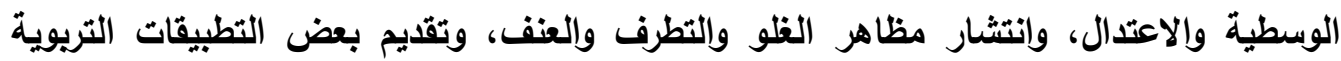

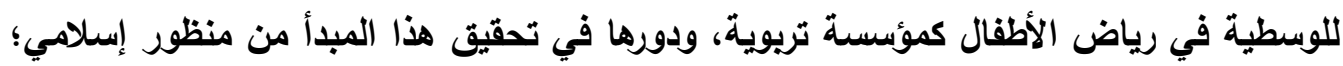
وذلك لضمان تحقق الأهداف التريوية الإيجابية في ضوء التربية الإسلامية، كما أنه يعد استجابة

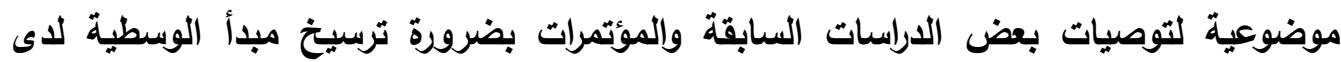
الأجيال، كما يفيد في نثر مبدأ الوسطية في العملية التريوية.

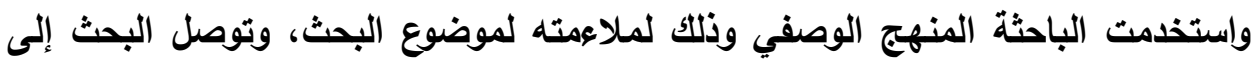
مجموعة من النتائج وذلك في ضوء الدراسة التحليلية التي قامت بها الباحثّة ومنها: - - أن التربية الوسطية التي لا تميل إلى الإفراط أو التفريط هي التربية المتوازنة المعتدلة التي تبني جيلاً صالحًا يطبق منهج الوسطية في كل حياته. - - ضرورة تربية أطفال الروضة على الوسطية الإسلامية، لتحصينهم من الأفكار المتطرفة والمنحرفة، وأن التربية الوسطية يجب أن تُغرس وتُرسخ من بداية الطفولة حتى تؤتي ثمارها المرجوة. أهمية مؤسسات رياض الأطفال ودورها الخطير الذي تلعبه لغرس وتعزيز مبأ الوسطية في نفوس الأطفال. ضرورة إكساب الأطفال مهارات التفكير النقدي والعلمي، وعدم التقليد بدون وعي أو فهم. الكلمات المفتاحية: تربية الأطفال - الوسطية في الإسلام - رياض الأطفال. 


\begin{abstract}
The present study aimed to investigate the concept and features of moderation in Islam, to identify the role of kindergarten stage in raising the child on moderation, to define the educational applications of moderation in kindergarten, to help activate moderation in kindergarten, and to take a stand towards the ideas of deviation and extremism.

The importance of this study stemmed from the importance of the issue it discusses as achieving moderation among the members of the Muslim community is a social and educational necessity anytime and anywhere. Besides, activating moderation establishes stability in the entire community, especially in the present time that suffers from the lack of moderation and the prevalence of fanaticism, extremism, and violence. Moreover, the study presents some educational applications of moderation in kindergarten, as an educational institution, that plays a role in achieving this principle from an Islamic perspective to ensure the achievement of positive educational goals in the light of Islamic education. It is an objective response to the recommendations of some previous studies and conferences on consolidating moderation among the generations. It may also help disseminate moderation in the educational process. The researcher adopted the descriptive approach because of its appropriateness to the topic. Based on the analytical study, a set of results were concluded. For example:

- Moderate education that does not tend to overuse or alienation is the balanced and moderate education that raises a good generation, which applies moderation.

- Raising child on moderation in Islam was highly concerned to prevent them from having deviant and extreme ideas.

- Moderate education should be fostered since early childhood to produce its expected results. Kindergartens play a considerable role in fostering moderation among children.

- Children should acquire the skills of critical and scientific thinking and avoiding imitation without understanding.
\end{abstract}

Keywords: Child education- Moderation in Islam- Kindergarten. 


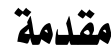

يمر المجتمع في الوقت الراهن بمتغيرات وتحديات متعددة نتيجة التقدم السريع في تكنولوجيا الاتصالات والمعلومات التي اخترقت المجتمع بأكلـه، كما أن مـا يشهره العالم من

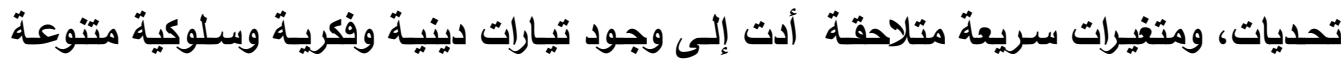
ومتطرفة تعمل على هدم مبادئ الإسلام الحنيف، ونشر الأفكار التي تتنافى مع تعاليم الإسلام الذي يؤكد على الوسطية والبعد عن الظلو، والتطرف لضمان استقرار المجتمع وتقدمه. فقد أصبحت الوسطية وتطبيقها في المجتمعات المعاصرة مطلبًا واقعيًا، ومنهجًا وقائيًا يقي الأمة من خطر الغلاة وإلمتطرفين، فالأمة تثـه خطرين لا يقل أحدهما عن الآخر، فإذاذا

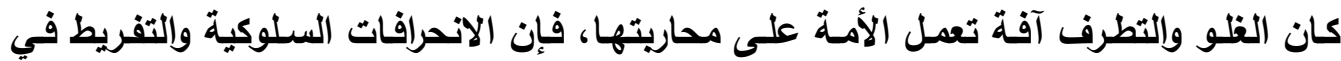
الثوابت والمعتقات آفة أثند لأنه لم يظهر الغلو والتطرف إلا كحركة مضادة للإفراط والتفريط

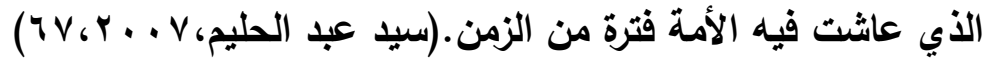

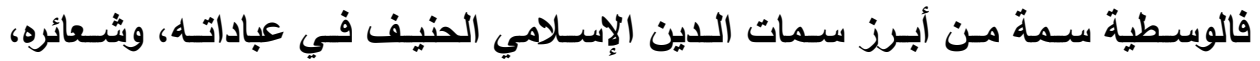

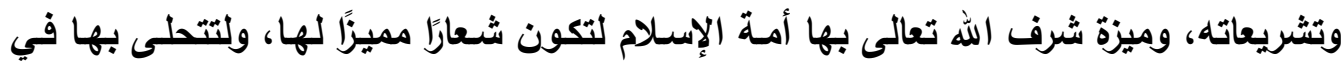

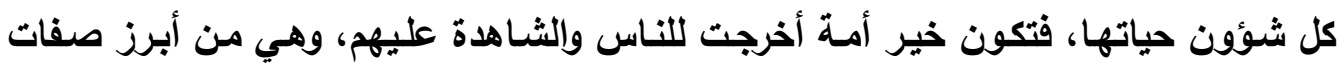

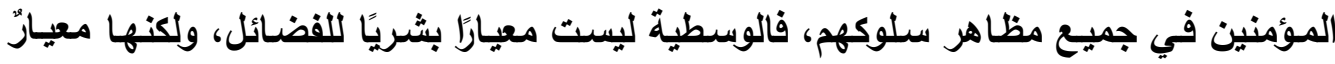

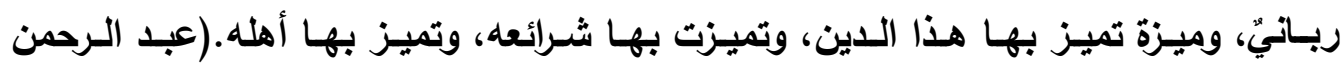

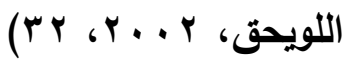

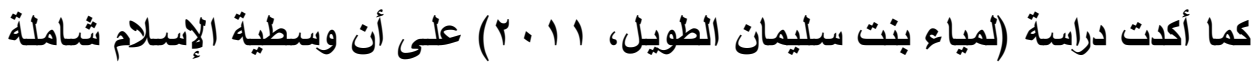

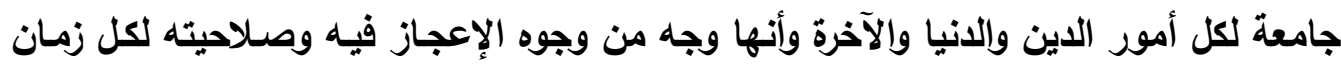

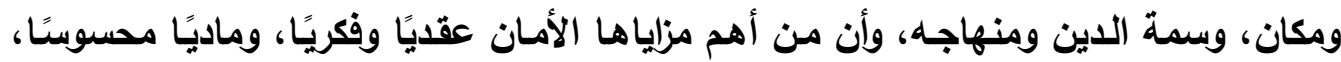
والبعد عن الخطر والإفساد في الأرض.

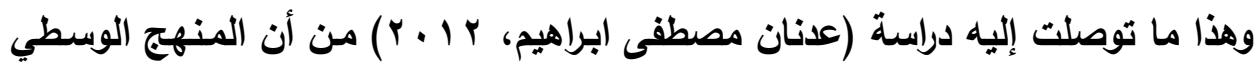

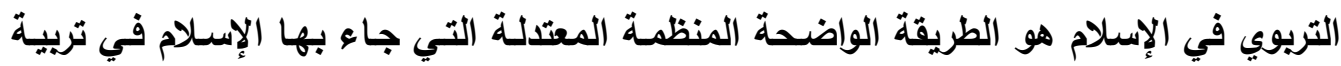

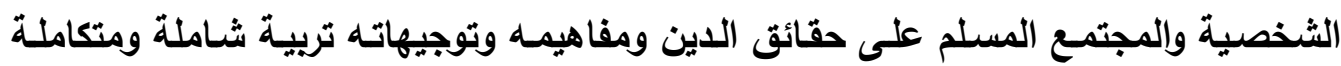
ومتزنة يحقق السعادة في الانيا والآخرة، كما أن المنهج الوسطي التربوي في الإسلام ينتمي 
إلى حلقة أوسـع هي المنهج الوسطي الإسـلامي الثـامل وهو خصوصية مـن خصوصيات الأمة، يعبر عن عقيدتها وهويتها وغاياتها.

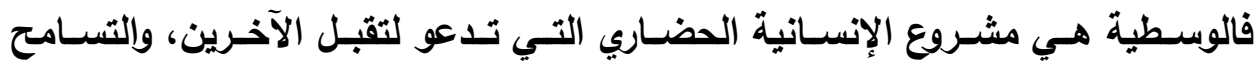

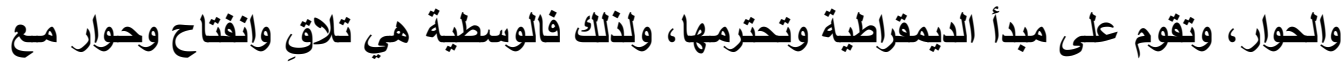
الآخر باختلاف ثُقافته أو دينه أو جنسه، وتنبذ التطرف والعنف والإرهاب.

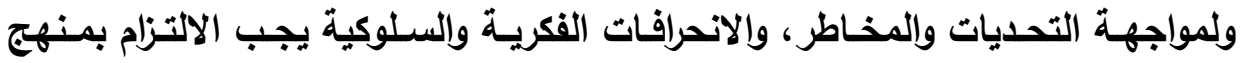
واحد وعدم الخروج والانحراف عنه، وهو المنهج الأفضل والأعدل وهو المنهج الوسط الذي الذي

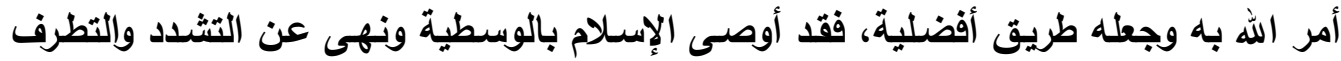
في جميع شؤون الحياة. كما أن الأخذ بالوسطية يحقق الخير والاستقرار للفرد وللمجتمع وهذا مـا أكلته الكثير

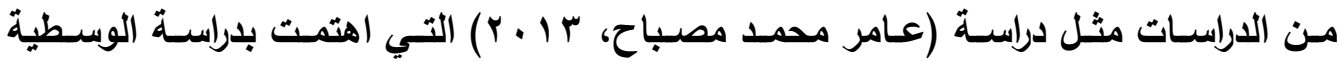

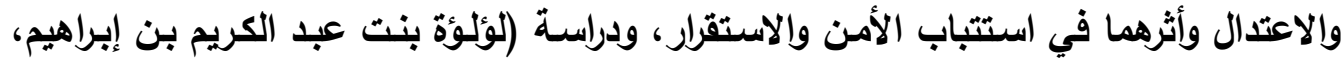

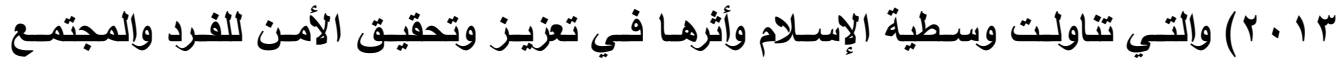
وحمايته من الانحراف والمغالاة والتطرف، ودراسة (ألفت حلمي أحمد وآخرون، 14 ـ ـ ب) والتي أكلت على أن الوسطية هي الميزان العادل الذي يحقق السعادة في الحياة، ودراسـة (رقية

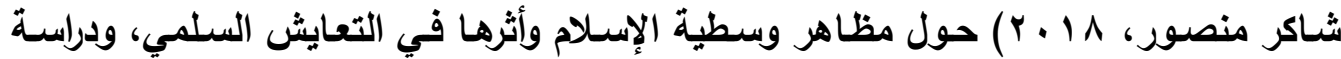

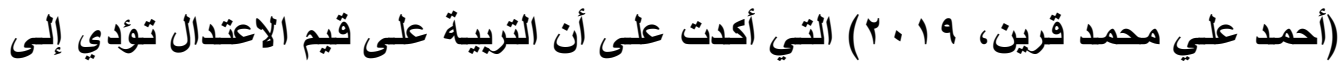
تماسك المجتمع وتوحيده، وذلك من خلال تحقيق التكامل والتضامن بين أفراد المجتمع.

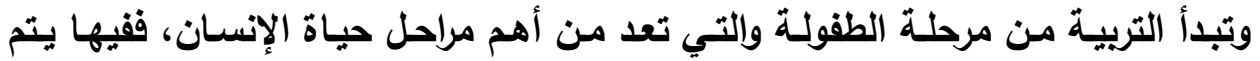
إرساء قواعد الثخصية في جميع جوانبها، فما يتعلمه الطفل في هذه المرحلة يؤثر بثكل

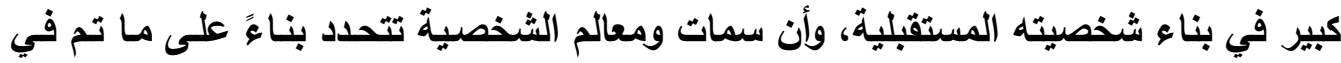

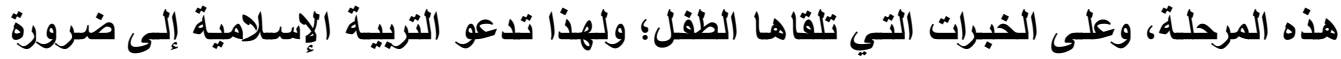
الاهتمام بتربية الطفل وإعداده في ضوء مبادئ الإسلام التي تدعو إلي الوسطية والاعتدال

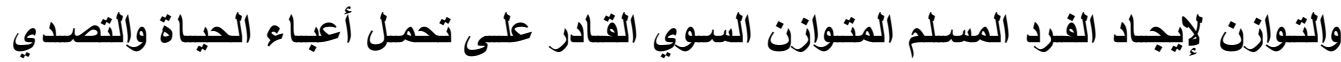
للأفكار التي تدعو إلى التطرف والانحراف. 
ولذلك يحتاج الطقل إلى فهم الإسلام على صورته الحقيقية، خاصة في هذا الوقت الذي

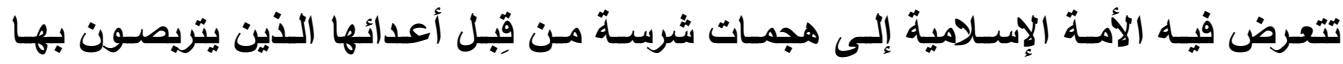
ويحاولون تثويه صورة الإسلام وأهله، وإهدار طاقاتهم، وإفساد أخلاقهم وقيمهم، إذ يصفون الإسـلام وأهلـه بـالعنف والعدوان والتطرف والإرهـاب، متجـاهلين الوسطية التـي يتبناهـا الدين

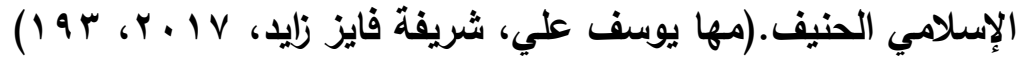
وأصبحت الحاجة ماسـة إلى تفعيل الوسطية من خلال رياض الأطفال، والتأكيد عليها

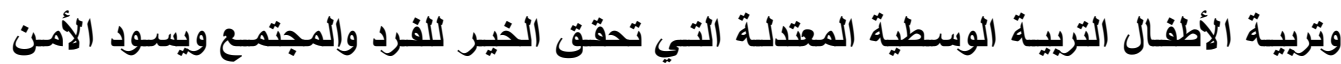
والأمـان، حيث إن الأطفال هم شباب المستقبل وينـاة المجتمع، فإذا مـا أحسن تربيتهم دون تفريط أو إفراط ولا تقصير أوتثدد لأصبح المجتمع كله يعيش في أمن وسلام وإنسجام. فرياض الأطفـال هي المؤسسـة التريويـة التي ترعى الطفل وتهيئه للمدرسـة الابتدائية، كما تعد رياض الأطفال حلقة الوصل بين الأسرة والمدرسـة والتي يتم فيها تربيـة الطفل وفق لرقي معايير وفلسفة المجتمع، وفيها تتشكل ملامـح شخصية الطفل المستقبلية، وينبغي أن تعمل رياض الأطفال على ترسيخ وتعزيز الوسطية في نفوس الأطفال.

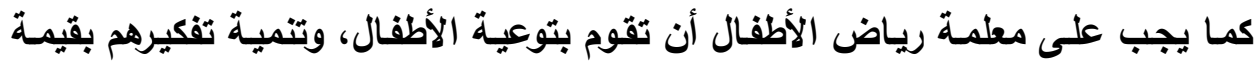
الوسطية كمبدأ إسلامي وتربوي يهدف إلى نبذ التطرف، والعنف، والغلو، والتشدد وتأكيده في

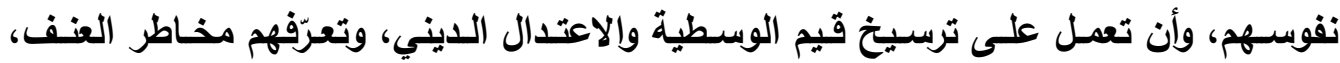
والتطرف، والثلو الايني. ومن هنا جاء البحث مهتمًا بتربية الطقل على الوسطية في الإسـلام وذلك للتظلب على بعض المشكلات التي تواجه عملية تربية الطقل وإيجاد الحلول لها. مشكالة البحث تتعرض المجتمعات الإسلامية لهجمات شرسة من أعداء الإسلام، وتحديات كبيرة تتمثل في انتشار ظواهر متعددة كالعنف، والتطرف، والإرهاب، والعديد من مظاهر السلوك المنحرف التـي تهـف إلى تذويب الهويـة الإسـلامية، كمـا أنها تواجها مخـاطر الغزو الفكري والتتريب الثقافي بمـا يحمله من أفكار هدامـة تؤثثر على سلوك بعض الأفراد، وخاصـة الأطفال، ممـا يستوجب تربيتهم وغرس قيم ومبـادئ الإسـلام؛ لحمـايتهم والتصدي لمخـاطر الغزو الثقافي 
حيث تواجه الأمسة الإسـلامية في العصر الحسالي عدة تيـارات فكريـة مناهضـة للإسـلام

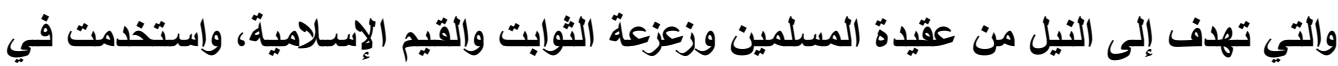

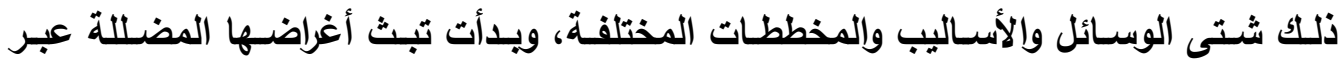
الوسـائل المختلفة من فضـائيات، وشبكات للمعلومـات، وألعاب الكترونيـة، وقد تسللت هذاته

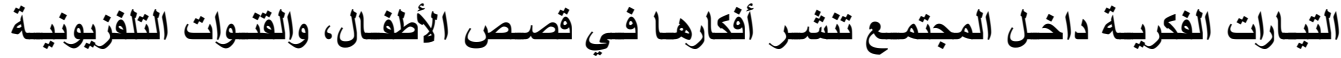

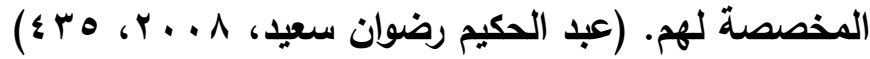
فوسائل الاتصال تؤدي دورًا خطيرًا في نقل صور العنف المختلفة، حيث أصبح العنف الموضوع المشترك فيما يعرض في وسائل الإعلام في برامج الأطفال، والأفلام، والمسلسلات، وكل ذلك انعكاس لموجة العنف التي تجتاح العالم اليوم. حيث يقضي الأطفال أمام شاشات فئات التلفاز، والأجهزة الذكية كالآيباد، والهواتف، وأجهزة الكمبيوتر أوقاتًا طويلة يثـاهداون الأفلام

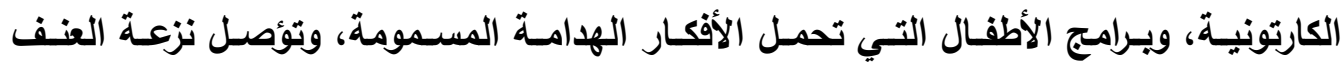
والعدوان في نفوسهم، وتحمل في طياتها الكثير من الأفكار المتطرفة المنحرفة التي تضرب التهاب بالقيم الدينية والأخلاقية عرض الحائط لكي تبني أجيالًا منحرفة عن مبادئ الإسلام وفضائلها.

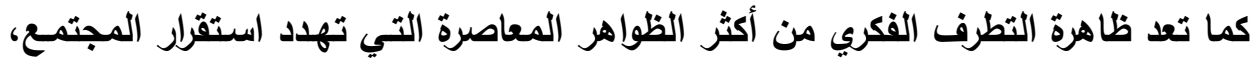
بما يمثله هذا التطرف من تدمير للثوابت، وتلاعب بالأصول القيمية المتعارف عليها، وتهدف ظاهرة التطرف إلى تدمير استقرار المجتمعات واستنزاف طاقاتها الفكرية، وخلق فوضى التفكير

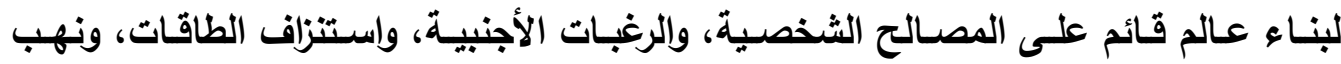

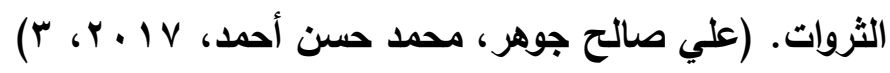

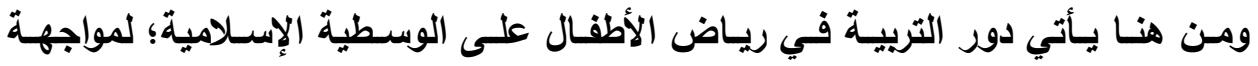

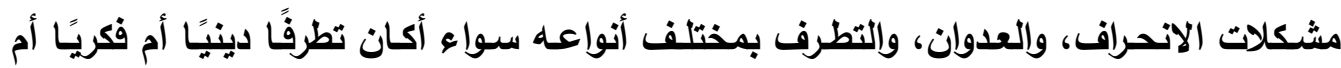

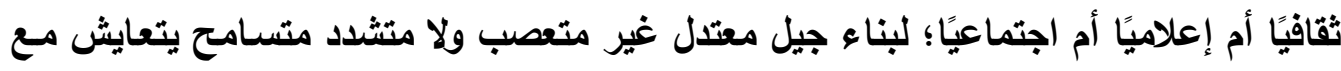
الآخرين بعيدًا عن الظلو والتطرف والإرهاب مما ينعكس على أمناء المناء المجتمع واستقراره. ونظرًا لأن مرحلة الطفولة هي التي تكوّن الصورة الثخصية للإنسان، وتثكّل ملامحسه

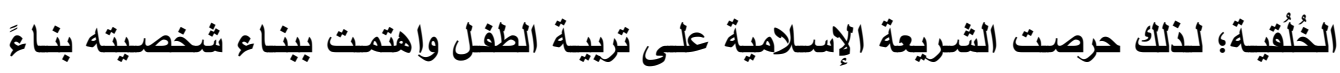
سليمًا مبتعدة عن أثنكال الانحراف، وأنواع العقد السلوكية، ومعظم الأمراض النفسية الخطيرة،

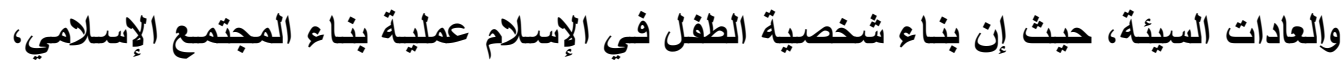


وأن نجاح الأهداف الإسـلامية وسـعادة الفرد والمجتمـع تتوقف على سـلامة عمليـة التربيـة.

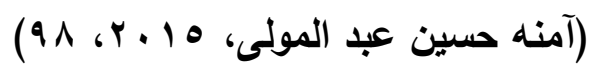

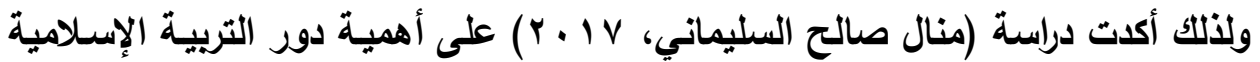
في مواجهـه مظـاهر الخلـل الفكري والثقافي الذي قد يـؤدي إلـى تثـويه وإضـعاف الهويـة الإسلامية، وتربية الأطفال التربية الدينية الصحيحة التي تغرس في النفوس العقائد السليمة الراسـخة، وينـاء الثخصـية القويـة، والثهويـة الميـزة حتـي يتمكنـوا مـن مواجهـة التحديات والمخاطر التي يتعرضون لها من قبل أعداء الدين الإسلاهي. ولذا يتوجب على رياض الأطفال الاهتمام بالتربية الدينية للأطفال، وغرس قيم ومبادئ الإسلام؛ لتكوين الوازع الديني لديهم، وتكوين الفكر الواعي المستنير منذ الصغر، وتنشئتهم التنشئة السليمة في جميع جواتب شخصياتهم. حيث ترى دراسـة (محمد النصر حسن، 10 ـ ب) أن ضعف التشـئة الفكريـة هو أحد

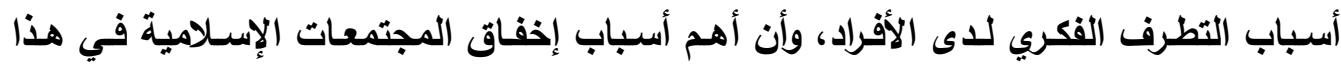
الصـدد هو تجاهـل دور التربيـة أو الإعراض عن هذا اللدور، كمـا أن التغيرات الاجتماعيـة والثقافية التي يمر بها العالم تفرض على القائمين على العملية التربويـة مسؤوليات مضاعفة تتجاوز حدود التعليم في نمطيته التقليدية، وأن يقوموا بدور أكثر أهمية في تشريب الناشئة المعايير والقيم التي تحافظ على أمن واستقرار المجتمع من خلال الوسطية بعيدًا عن الشطط والانحراف.

ومن هذا المنطلق تأتي أهمية تربية الطقل على مبدأ الوسطية الإسـلامية وحمايته من سيل التيارات الفكريـة المنحرفة المتطرفة، وأن تعمل مؤسســات ريـاض الأطفال على ترسيخ وغرس الوسطية في نفوس الأطفال لتكون لهم حمايـة ووقايـة من تلك التيارات والتطرف، والانحراف بكل أشكاله.

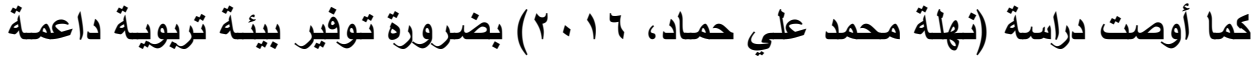
للأمن الفكري، وغرس القيم الإسـلامية الصحيحة في نفوس الأطفال لحمـايتهم مستقبلًا من دعاة الفكر المنحرف عن قيم ومبادئ المجتمعى، والتأكيد على تفعيل دور المؤسسـات التريوية في مواجهة الغلو والتطرف والأفكار المتثددة، والتأكيد على دور المدارس في ترسيخ قيمـة الوسطية وذلك بتوفير المعلمين والمعلمات المعتدلين سلوكيًا وفكريًا وعقائديًا. 
ونظرًا لخطورة بعض الأفكار المنحرفة المتطرفة الوافدة من الغرب والتي تستهدف أطفال المجتمع المسلم؛ جاء هذا البحث لتسليط الضوء على أهمية تربية الأطفال على الوسطية الإسلامية، وضرورة تربيتهم التربية الوسطية المعتدلة، وتنمية وعي الأطفال، وتحذيرهم من مخاطر العنف والتطرف والاتحراف التي تمس أمنهم وسلامتهم وعقيدتهم الإسـلامية، ومن هنا تتحدد مشكلة البحث في تربيـة الأطفـال على الوسطية في الإسـلام وتطبيقاتها في ريـاض الأطفال، وجاءت تساؤلات البحث كما يلي:

\section{تساؤلات البحثث}

1- ما المقصود بالوسطية في الإسلام، وما أهم خصائصها؟ r - ما دور رياض الأطفال في تربية الطقل على الوسطية؟ ץ- ما التطبيقات التريوية للوسطية في رياض الأطفال؟ أهداف البحث استهافت الباحثة من إجراء البحث الحالي تحقيق الأهداف التالية: - تعرّف المقصود بالوسطية في الإسلام، وأهم خصائصها. - الوقوف على دور رياض الأطفال في تربية الطقل على الوسطية. - تعرّف التطبيقات التريوية للوسطية في رياض الأطفال. - الكثف عن أهمية التربية الوسطية وأثرها في تربية طقل الروضة. - المساهمة في تفعيل مبدأ الوسطية في رياض الأطفال والتصدي للأفكار التي لهي تدعو للانحراف. والتطرف. أهمية البحث - تنبع أهمية البحث من أهمية الموضوع الذي يناقشه، حيث إن تحقيق مبدأ الوسطية عند أفراد المجتمع المسلم يعد ضرورة اجتماعية وتريوية لازمة في كل مكان وزمان.

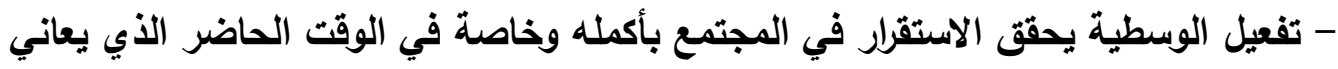
من افتقاد الوسطية والاعتدال، وإنتثار مظاهر الغلو والتطرف والكنف. - يقدم البحث بعض التطبيقات التربوية للوسطية في رياض الأطفال كمؤسسة تريوية، ودورها في تحقيق هذا المبدأ من منظور إسلاهي وذلك لضمان تحقق الأهداف التريوية الإيجابية في ضوء التربية الإسلامية. 
- يعد البحث دعوة للباحثين في الميدان التريوي للاهتمام بإجراء الدراسات المختلفة حول موضوع الوسطية.

- يعد هذا البحث استجابة موضوعية لتوصيات بعض الدراسات السابقة والمؤتمرات بضرورة ترسيخ مبدأ الوسطية لاى الأجيال. - يفيد البحث في نثر مبدأ الوسطية في العملية التريوية. مصطلحات البحث

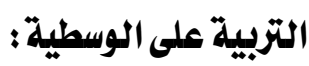

وتعرف بأنها التزام الاعتدال في تربيـة جميع جوانب المتطم وعدم مجاوزتها بالزيادة

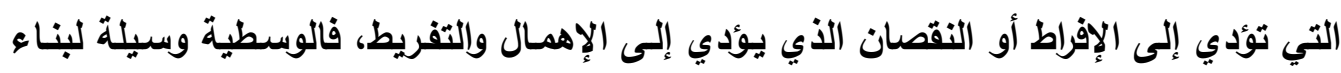

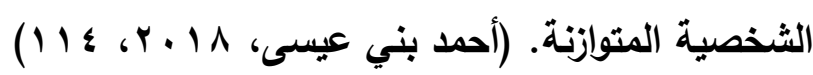

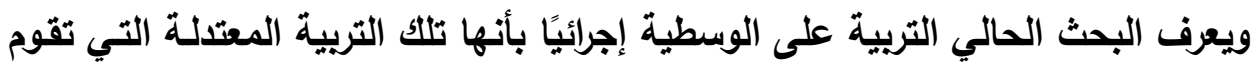

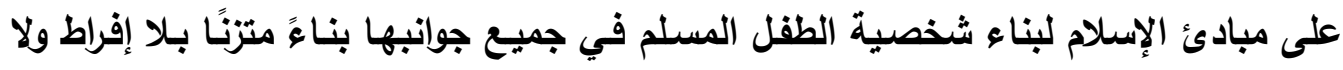

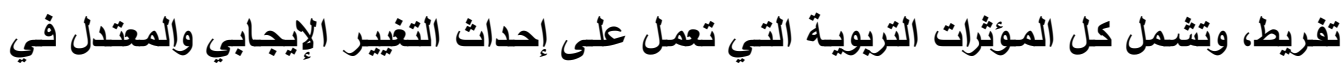

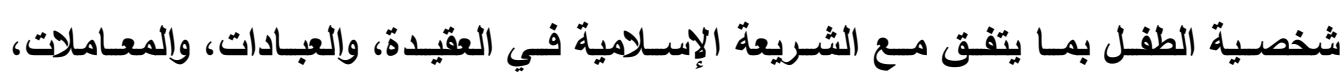

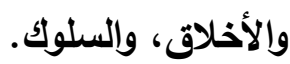

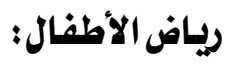

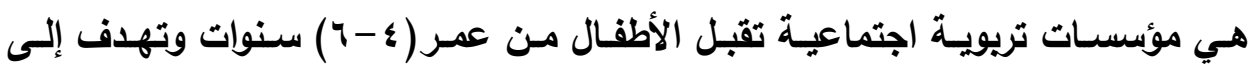

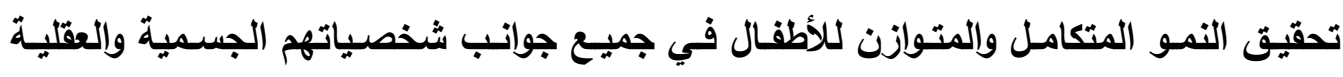
والأخلاقية والنفسية والاجتماعية والنفسية وتعمل على إعدادهم للالتحاق بالمدرسة الابتدائية.

منهج البحث

يعتمد البحث على المنهج الوصفي الذي يهدف إلى الإجابة عن تساؤلاته من خلال

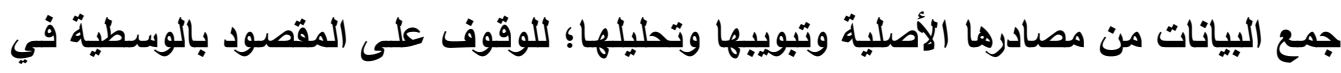

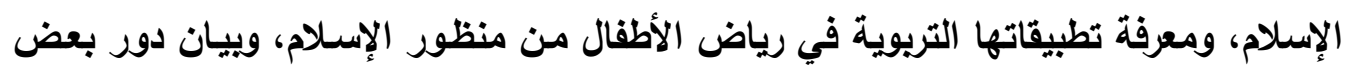
المؤسسات التريوية في تفعيل مبدأ الوسطية في العملية التريوية. واستخدم البحث المنهج الوصفي وفقًا للخطوات التالية: 
- - جمـع الدراسـات السـابقة والأدبيـات المتصـلة بموضـوع البحث وتحليلها وتحديد مثكلة

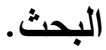

- - إعداد الإطار النظري للبحث بحيث يغطي المحاور العلمية التي اشتمل عليها البحث، والتأصيل النظري له.

- استنباط بعض التطبيقات التزبوية التي يمكن أن توجه عمل معلمة رياض الأطفال، وتفيد القائمين على العملية التريوية برياض الأطفال.

- - الوصول إلى نتائج البحث ووضع التوصيات والمقترحات بناءُ على الدراسة التحليلية.

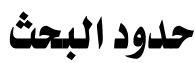

اقتصر البحث الحالي على تربيـة الأطفال على الوسطية في الإسلام وتطبيقاتها في

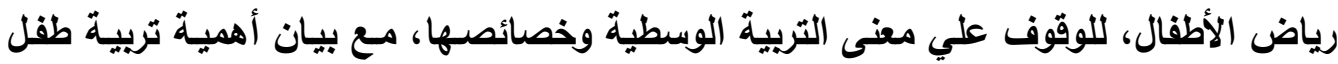
الروضة على منهج الوسطية، وتطبيقاتها في رياض الأطفال لبناء شخصية الطفل المتوازنة، والتصدي للأفكار المنحرفة والمتطرفة.

\section{خطوات السير في البحث}

بعد الاطلاع على الدراسات السابقة والأدبيات ذات الصلة بموضوع البحث الحالي

تبلورت مشكلة البحث وسارت الباحثة في بحثها وفقًا للخطوات التالية:

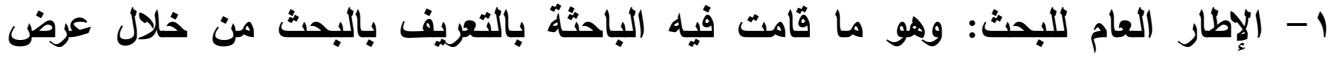
الدراسات السابقة ذات الصلة بموضوع البحث، وعرض مشكلة البحث وتساؤلاته وأهميته وأهدافه، وكنلك عرض حدود البحث ومنهجه ومصطلحاته وخطوات السير في البحث. r- الإطار النظري للبحث: وجاء الإطار النظري للبحث مكونًا من ثلاثة أجزاء هي: الإنه

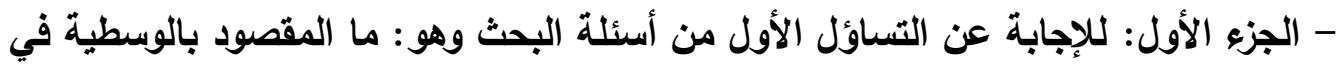
الإسلام، وما أهم خصائصها؟ قامت الباحثة بتعريف مفهوم الوسطية في الإسلام وأهم خصائصها. - الجزء الثاني: للإجابة عن التساؤل الثاني من أسئلة البحث وهو : ما دور رياض الأطفال

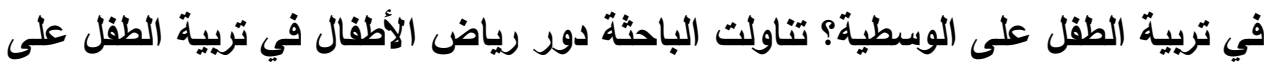


الجزء الثالث: للإجابة عن التساؤل الثالث من أسئلة البحث وهو: ما التطبيقات التريوية للوسطية في رياض الأطفال؟ تناولت فيه الباحثة التطبيقات التريوية للوسطية في

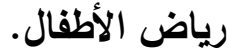

\section{الإطار النظري للبحث}

أولًا : مفهوم الوسطية في الإسلام وأهم خصائصها: تعد الوسطية من أبرز سمات الاين الإسلامي الحنيف وأحد المعالم الأساسية التي ميز

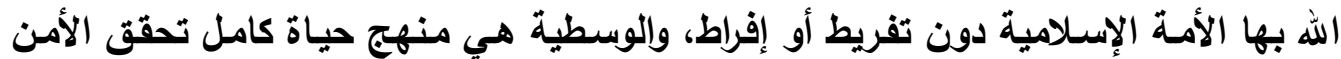
والاستقرار والسعادة والطمأنينة وإلخير للإنسان بعيدًا عن كل مظاهر التطرف والثظو.

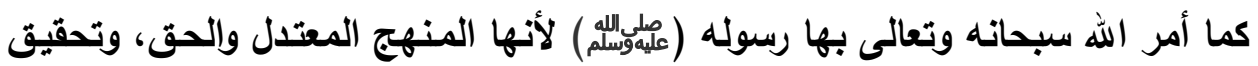
الوسطية الإسـلامية سبيل إلى الرقي في كل مجالات الحياه وسبيل إلى الانفتاح والحسوار وسعادة الدنيا والآخرة. والوسطية تغني الخيرية والتوسط بين أمرين فلا هي الإفراط ولا هي التفريط، وكذلك الاعتدال والتوازن في كل الأمور، كما أنها حالة خطابية أو سلوكية محمودة تعصم الفرد من الميل إلى جانبي الإفراط والتفريط، حيث تقيمه على طريق الاعتدال والتوازن

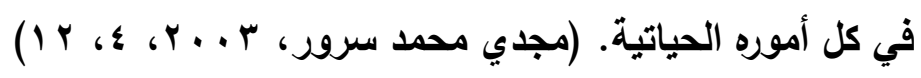

وتتميز الوسطية في الإسلام بأنها عكس الغلو والتثندد والتطرف، كما تتميز بأن لها

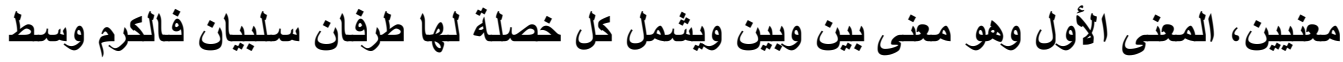

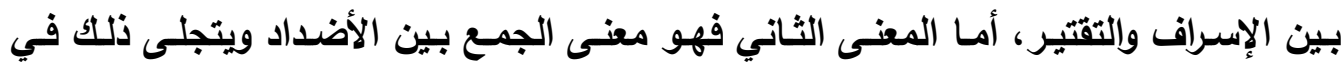

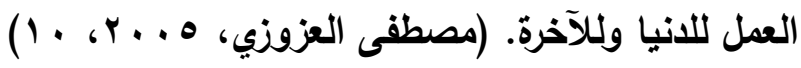

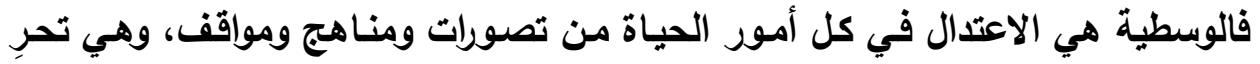
متواصل للصواب في التوجهات والاختيارات، وهي ليست موقفًا بين التثدد والانحلال، بل هي منهج فكري وموقف أخلاقي وسلوكي مرجعه الثرع، فما وافق الثرع فهو الوسط، والوسطية منهج أصيل ومفهوم جامع لمعاني العدل والخير والاستقامة. فهي حق بين باطلين واعتدال

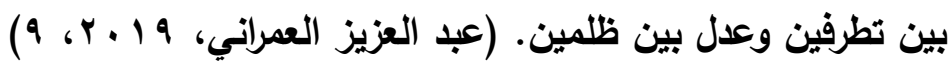

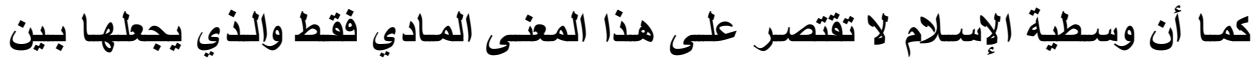
طرفين مذمومين، وإنما وسطية الإسلام أعظم وأثشمل من هذا المغنى فهي منهج حياه كامل ومتكامل جطها الله عز وجل سمة للأمة الإسلامية وميزها بها. 
فوسطية الإسلام تثمل جميع جوانب الحياة وجميع جوانب التشريع والتنظيم وإلعبادات والمعـاملات والعدل في سـائر التصـرفات، والتـوازن في كل المجريـات، كمـا تعنـي الوسـية الخيريـة والفضل وحسن السلوك والأخلاق، والأدب، وفي مقدمة ذلكت كله الاعتقاد الذي هو الإيمان بالله، وهي بذلك تعني جملة المحاسن والفضائل والعادات والتقاليد التي جرت عليها سنة الله في خلقه، وأبقاها الله وشرعها على لسـان الرسول (علئسلالم) لعموم الخلائق. (شوكت

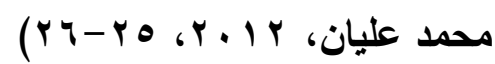
ويتضـح ممــا سـبق أن وسـية الإسـلام هـي طريقتهـه المحمـودة التـي تعصـم الإنســان وتحميه من الميل إلى جانبي الإفراط والتفريط أي تقيمه على ميزان الاعتدال في كل أموره،

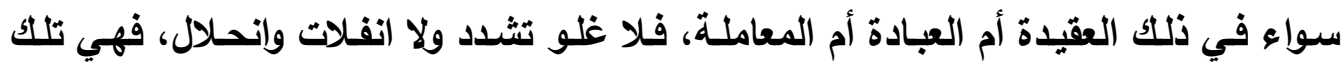
المنزلـة المحمـودة بين طرفين مـمومين وتمثثل حالـة التـوازن والاعتدال التـي لا إفراط فيها بالزيادة ولا تفريط بالنقصان. وللوسطية الإسلامية عظيم الخصائص، وجميل السمات مما جعلها آية من الآيات ومن هذه الخصائص والسمات ما يلي: | - الوسطية تربية ربانية: فمن أهم سمات الوسطية أنها إلهية الوحي ريانية المصدر قرتها آيات قرآنية وأحاديث نبويـة وهي من أعظم مقاصد الشريعة الإسـلامية المنزلـة من عند الله سبحانه وتعالى (عبد الهابه

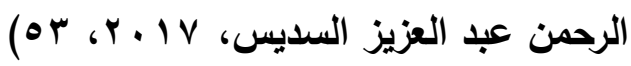
والقصد بالربانية أنها إلهية المصدر من عند الله عز وجل وليست من وضع البشر فهي

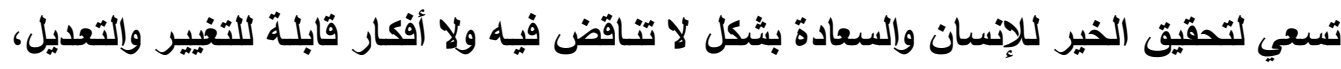
فهي تحرر الإنسان من الأوهام والانحرافات والأفكار الخاطئة. والربانية من حيث الهدف والغاية تعني أن المسلم في ظل التوجيهات الإسـلامية يبتغي بأقوالـه وأفعاله رضسى الله عز وجل، فالتوجيه الرباني يوجها الإنسـان لأفضل الأخلاق وأنبلها

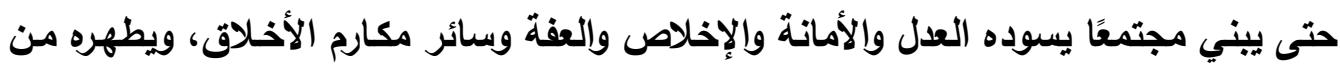

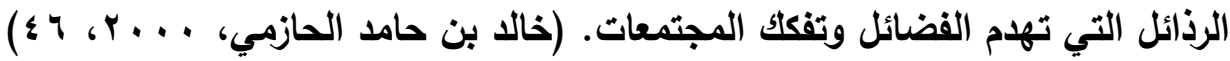

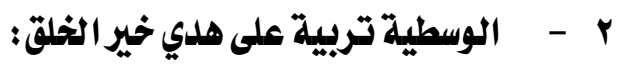


لم تكن الوسطية ولن تكون مجرد نصوص تُقرأ أو آيات تتلى، بل تجسدت وإقعًا مباركًا وسيرة عطرة في هدي خير الخلق سيدنا محمد (علهولسلله ) في أقواله وأفعاله على خير وجـه

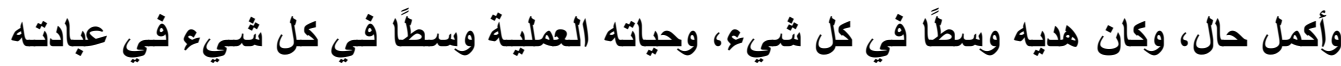

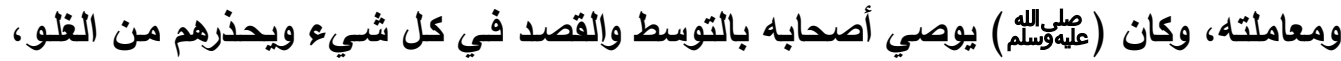

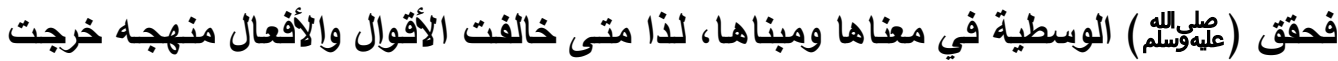
عن معناها، وإنحرفت عن مسماها، ومالت إما إلى إفراط أو تفريط. (عبد الرحمن عبد العزيز

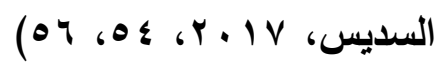
فمن أعظم سمات وخصـائص الوسطية كونها على هدي النبي (علمولاللهم)، وهو القدوة الحسنة لكل المسلمين والعالم أجمع، ووجب على الجميع الاقتداء به والالتزام بسنته ويتوسطه في الأمسور فكان (علهولسلهم) وسطًا في كل شـيء، ودعا إلى الوسطية و" مـا خُير رسول الله

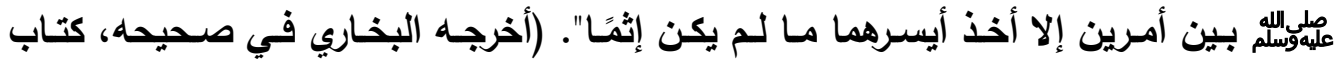

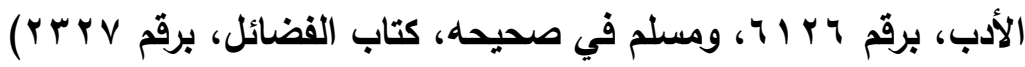
r - الوسطية تربية شاملة ومتكاملة: فالتربية الإسلامية شاملة لكونها تربي الإنسـان في جميع مراحله، كما أنها تربي الفرد

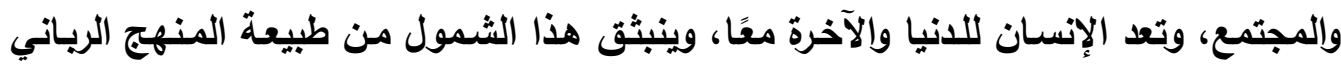
الأي شمل كل شئ، وأما تكامل التربية الإسلامية فهو ينسجم مع نظرتها الشمولية للشخصية الإنسـانية، ويتفق مـع تصـور الإسـلام لوحدة الإنسـان والإنسـانية جمعاء، فهو ليس جســا مستقلًا بذاته عن الروح والعقل، وليس عقلًا مستقلًا لا علاقة له بالجسم والروح، بل هو كيان واحد متكامل الأجزاء ويقدر مـا يكون توافق وإنسجام بين مكونـات الطبيعة الإنسانية روحًا وعقلًا، وجسدًا يكون تكامل شخصية الإنسـان وأي انحراف عن ذلك التوافق، يُلحق الضرر

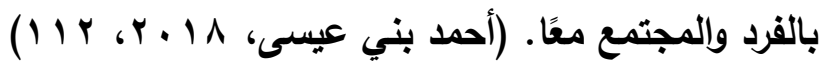
فالوسطية تربية شاملة ومتكاملة نظرًا لأنها تتبثق من الثريعة الإسـلامية التي تتصف التف بالثمول والكمال، كما أنها لم تهمل أو تففل أي جانب من جوانب الحياة بل شملت جميع جوانبها في الفكر والأخلاق والعبادة والعقيدة، فالوسطية منهج حياة شامل كامل متكامل يحقق ئق الاستقرار والأمان لكل البشر. ؟ - الوسطية تربية موافقة للفطرة: 
ومن السمات الضابطة لمفهوم الوسطية كونها موافقة للفطرة الإنسانية التي تأصل فيها التوسط والعدل، ونبذ الغلو والتطرف والجور، وإذا كانت الفطرة هي محبة الحق وقبوله وإرادته، وكان من أكبر مقاصد الثريعة وأعظم مـا أمرت بـه ودعت إليهه تحقيق الوسطية والاعتدال،

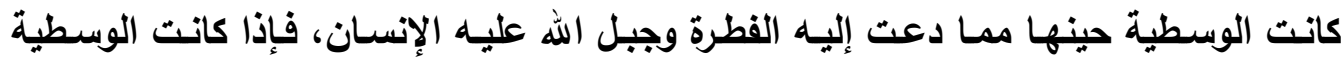
ريانية المصدر كانت بالضرورة مغروسة بالفطرة تولد مـع الإنسان. (عبد الرحمن عبد العزيز

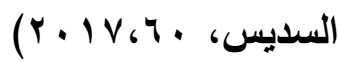
ففطرة الله التي فطر عليه الناس حب التوسط والميل إليه، والنفور من التشدد والمغالاة، وطاعة الله عز وجل والاستقامة على الدين، فقد خلق الله سبحانه وتعالى العباد كلهم حنفاء محبين للتوحيا ومستعدين له، وتلك الفطرة موجودة عند كل إنسان مالم تفسد.

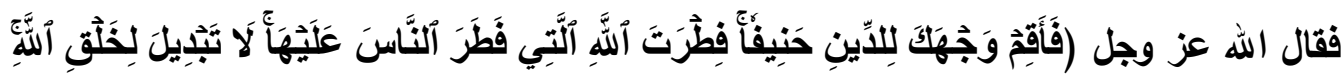

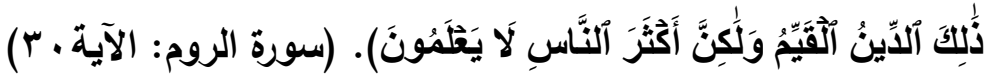
0

فالوسطية متدرجة اتباعًا لمنهج الإسلام في دعوتهه الناس إلى العقيدة الصحيحة وفيما

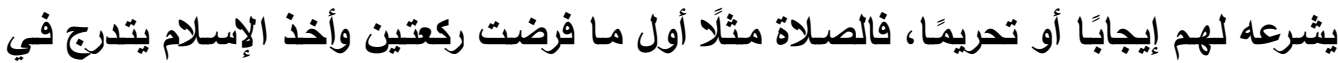
تفصيلات هذه الفرائض وغيرها شيئًا فشيئًا كلما ازداد المجتمع الإسـلامي استعدادًا لها، وهذا

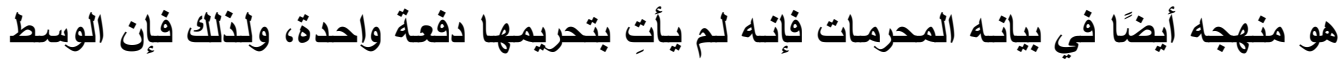

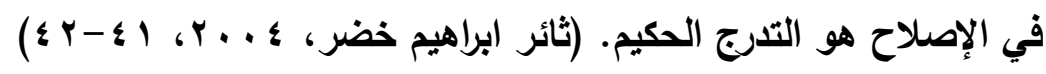

كمـا تكمن أهميـة التربيـة في بلـوغ الكمـال الإنسـاني بالتـريج. ذلكت أن التربيـة نفسهـا

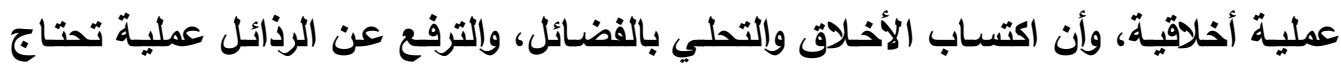
إلى وقت حتى يكتسب الفرد أنماط السلوك المرغوب. والإسـلام في تربيته للمسلمين الأوائل لم

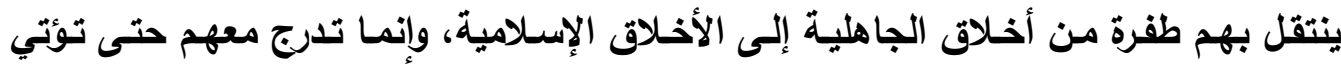

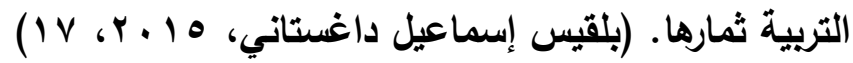
ومسن أهداف التربيـة الإسـلامية التـدرج لبلـوغ الكمـال الإنسـاني ووفقًا لطبيعـة الإنسـان ومراحل نموه، فالتربية الإسـلامية متدرجة من أجل تثبيت العقيدة والإيمان بـالله بشكل متدرج بعيدًا عن الإفراط والتفريط. 
I

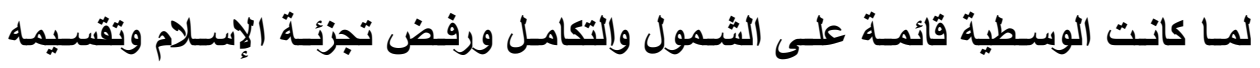
وتحذيرها من الأفكار الهـامة والاتجاهات المنحرفة، كان عمرها طويلًا واستمرارها في مناهج الحياة المثالية خالدًا، وأثرهـا في الفرد والمجتمـع باقيًا بخلاف التطرف والتعصب وإلغلو فإنـه يكون دائمًا قصير العمر مهما طال. (ثائر ابراهيم خضر، ؛ ؟ . . Y، 0 ؛ ) حيث تمتـاز التربيـة الإسـلامية بثبات أصولثها، فهي تقوم على مجموعة من الحقائق الثابتة، لا تتغير بتغير الزمان ولا المكان، فهي ثابتة في حقائقها المتصلة بالعقيدة والعبادات والنظم والتشريعات، وثثابتة في أصول القيم والأخلاق، ومن الحقائق الثابتة للتربية الإسـلامية

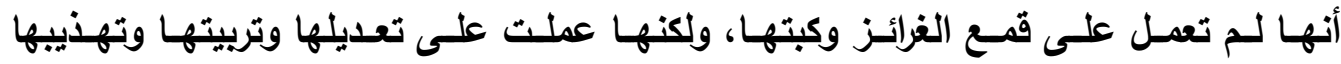

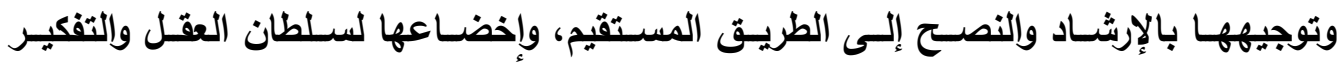

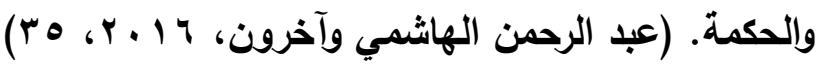
فهي مرنة ذات أصول ثابته، ثابتة في العقائد والعبادات والأخلاق، ومرنة في تطبيقاتها، ومتجددة غير جامدة صالحة للتطبيق في كل زمان ومكان، مراعية لتطور وتغير الحياة لكي تفي بحاجـات المجتمعات والمسلمين على مر الأزمـان. والوسطية تتميز بالثبات والانضباط والمرونة لأنها من أهم مقاصد الثريعة الإسلامية ومنهجها الثابت.

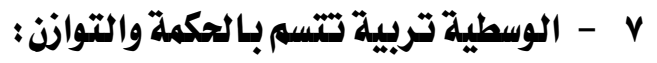
تعد الوسطية القاعدة الكبرى في التربية الإسلامية، والإسلام يرى أن الغلو كالتفريط يخل بالتوازن وهو يعترف بقيمة الفرد ويحمله المسئولية الفردية، والإسلام لا يمحق الفرد ولا يهمل وجوده، كمـا أنـه لا يتطرف في الفرد على حسـاب الجماعة، فالفرد شخصية مستقلة ولكنهـ عضو في جماعة متحدة الهدف وفي العمل وفي النهايـة ترتبط بـالله سبحانه وتعالى، ويتمثل

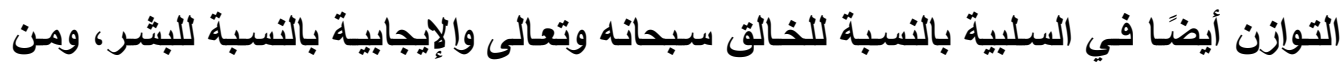

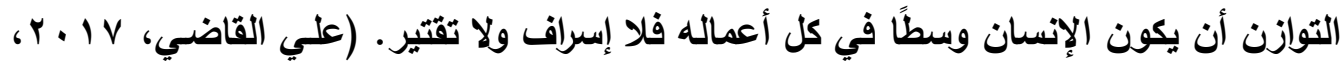

ويعنـي التـوازن الاهتمـام بتربيـة جميـع جوانـب الفـرد الجسـيـة، والخلقيـة، والعقليـة، والنفسية، وكافة جوانب الثخصية، وأيضًا التوازن بين المطالب الجسمية والروحية بحيث لا يطفى جانب على آخر وتحقيق التوازن يعني التوسط في الأمور بـلا تفريط أو إفراط حتى لا 
يعيش الإنسان في صراع نفسي وداخلي، فالتوازن يحقق السلام والأمن النفسي والطمأنينة

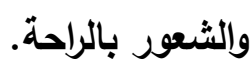
1 - الوسطية تربية سليمة خالية من التناقض :

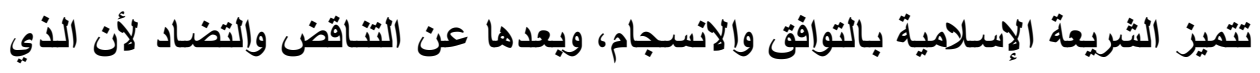

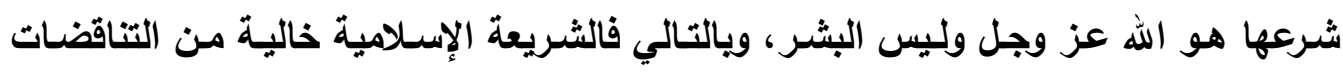

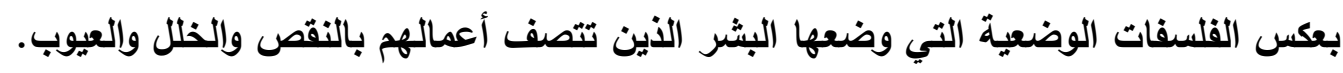

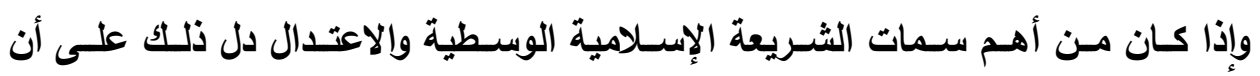

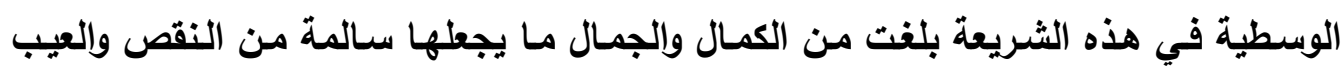

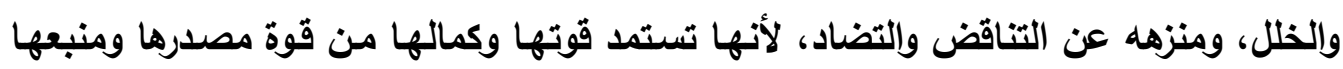

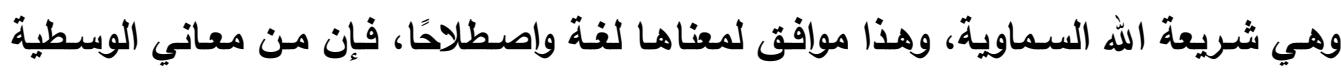

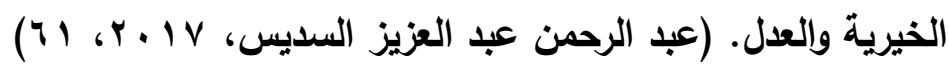

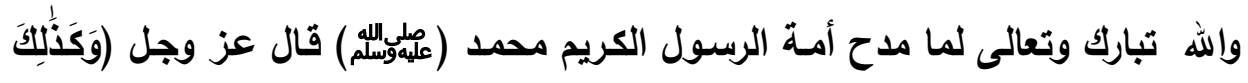

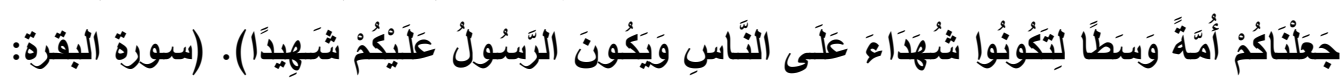

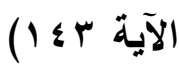

\section{9 - الوسطية تربية خالية من الفلو:}

إن منهج الوسطية موافق للشـرع وموافق للعقل السليم، فالثـرع الصـيح بنصوصـهـ

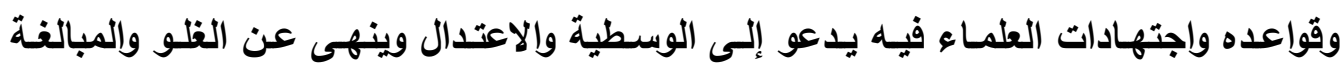

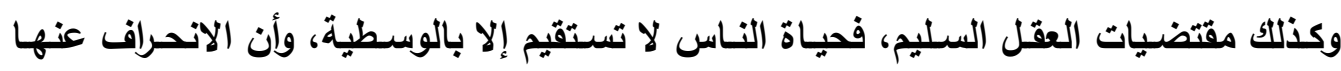

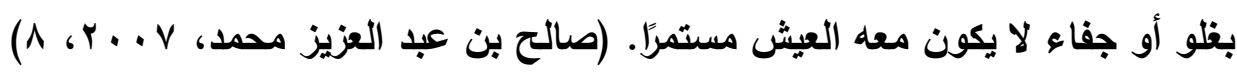

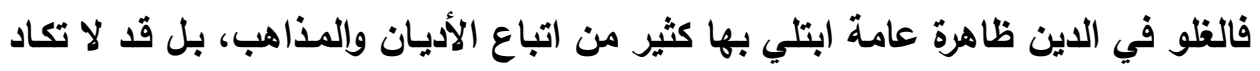

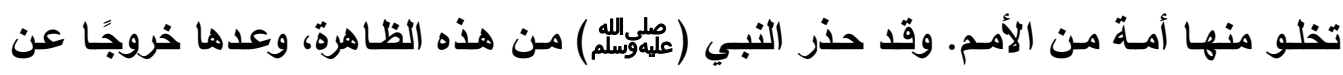

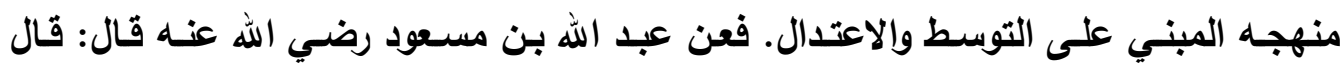

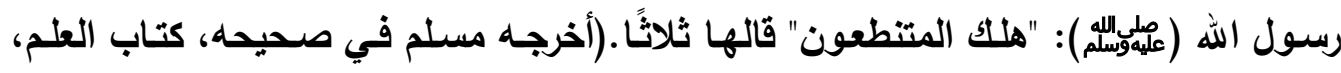

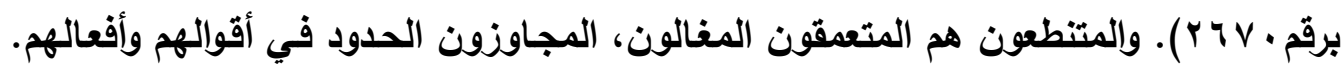

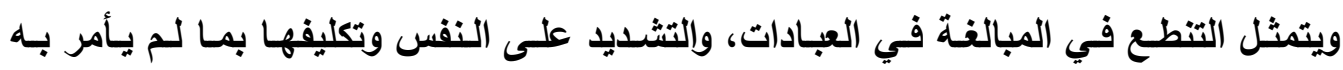


الشرع، واجتناب الرخص المشروعة بقصد العبادة والتقرب إلى الله تعالى. (فتح الدين محمد

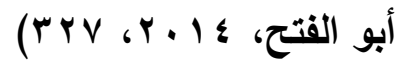
فالشريعة الإسـلامية تتهى عن التفريط والإفراط والتلو والتطرف، وتدعو إلى الوسطية

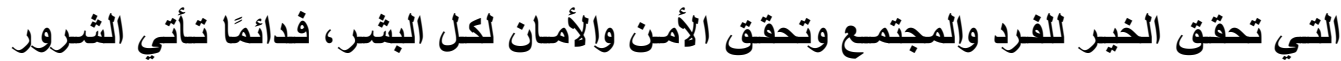
والمشكلات نتيجة البعد عن منهج الوسطية والتطرف، والظلو، والتشدد. 1. تعد التربيـة على الوسطية عملية إنسـانية هدفها إعداد الإنسـان الصـالح، والمجتمـع المتوازن مـن خـلال مراعاة القيم الإنسـانية، والتأكيد على الوحدة بين البشـر وعدم التفرقة بينهم بسبب الجنس أو العرق أو الدين، فهي تربية إسلامية تؤكد على قيم التسـامح والرحمـة الإسة

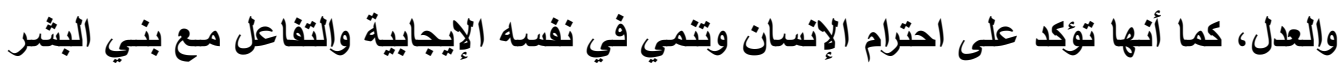
باختلاف أجناسهم وأديانهم. فقيم العـل، والحـق، والخيـر، ومراعـاة مشــاعر الآخـرين، وحقـوق الأقـارب واليتـامى

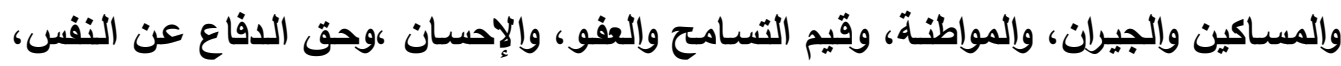
وغيرهـا مـن القيم الإنسـانية داخلة في صميم الوسـية الإسـلامية، فالقيم الإسـلامية سبقت الهيئـات والمنظمـات الإنسـانية في وضـع ضـوابط الآداب، ومعرفـة الحقـوق والواجبـات، وقد الإند صارت هذه القيم معايير أساسية وقيمًا مراعية لمفاهيم الحقوق الإنسـانية والبشرية، والتي لا يمكن للناس من دونها أن يعيشوا بكرامة كبشر، وهي أسساس الحريـة والعدالة التي تنادي بها

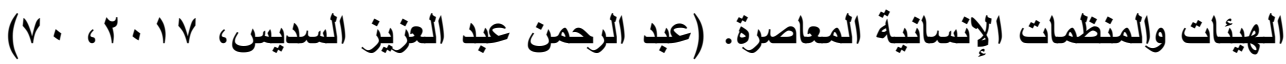
ثانيًا: دور رياض الأطفال في تربية الطقل على الوسطية:

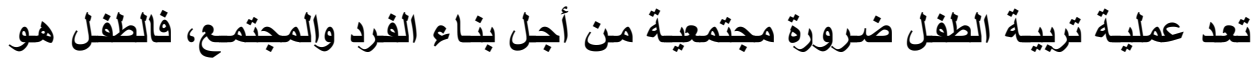
أسـاس المجتمـع، والتربيـة هـي أداة للتغيير والتطوير وينـاء شخصية الطفل بمـا ينسجم مـع ثقافة المجتمع، وتعد عملية تربية الطقل من أصعب المهام التي يمكن القيام بها نظرًا لأن مـا يتم غرسه في نفوس الأطفال في هذه المرحلة الخطيرة سيستمر معهم طيلة حياتهم. وتعد مؤسسات رياض الأطفال من أهم المؤسسـات التريويـة التى تتولى مسئولية تربية

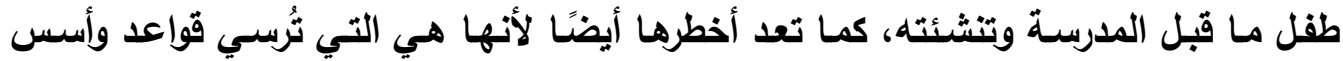


التربية وتغرس مبادئها، وأن التربية في المراحل التالية لها تُبني وتقوم على مـا تم وضعه في تلكك المرحلة، ولذا تعد تلك المؤسسات من أخطر وأهم المؤسسات التريوية. وفي تلك المرحلة يجب أن يتم تربية الطفل وفق مبادى ع الشريعة الإسـلامية، وترسيخ

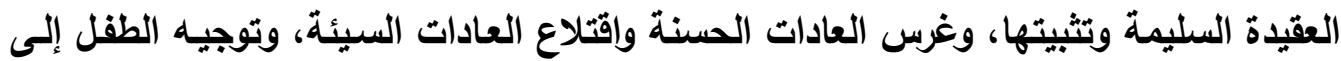
الأخـلاق الفاضـلة التـي دعـا إليهـا الإسـلام، ففي تلكـ المرحلـة يمكن توجيـه الطفل بسـهولة ويالتالي يمكن تربيته على منهج الوسطية وترسيخها في نفسه ونبذ الغلو والتطرف والتعصب. فتأسيس العقيدة السليمة منذ الصغر أمر بالغ الأهمية في منهج التربية الإسـلامية،

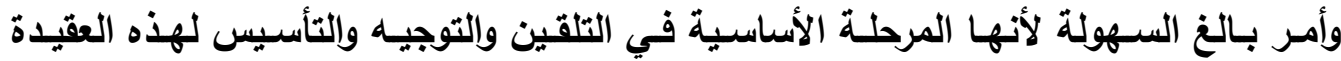
السليمة، وعلى المريين أن يقوموا بذلك في ضوء المنهج الإسلاهي الصحيح النابع من القرآن

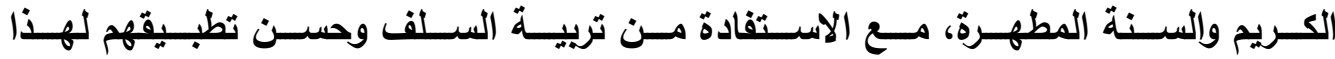

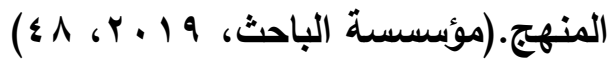

ولذلك يجب تربية الطقل على الوسطية في مؤسسات رياض الأطفال باعتبارها مؤسسة

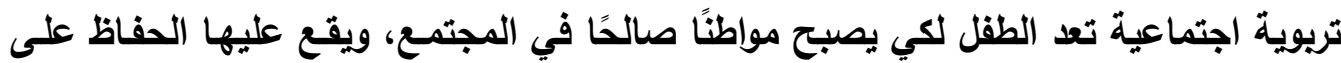
الأطفال من خلال ترسيخ الأسس الإيمانية والفكرية بما تتضمنه من معاني الوسطية التي دعا لـولية إليها الإسلام، والعمل على تهذيب سلوكه وأفعاله وأقوالـه منذ الصغر حتى يكون للدى الطفل الوعي الكامل بما يحدث حولهه في المجتمع وينشـأ على منهج الوسطية ونبذ الغلو والتطرف

فالتربية الصحيحة تؤدي دورًا كبيرًا في غرس وتعزيز الوسطية عند طفل الروضة فكرًا وسلوكًا، قولًا وعملً، ولا يمكن تحقيق ذلك إلا من خلال تقديم الكتاب والسنة للطفل، وتربيته فرله على القيم والأخلاق الإسـلامية، ويـللك تستطيع رياض الأطفـال أن تحقق الوسطية في تربية أطفالاها.

حيث يعد موضوع الوسطية من الموضوعات التي ينبغي أن يعني بها المربون وذلك

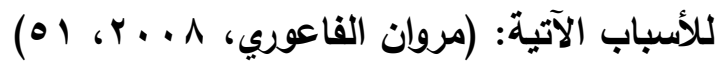

إن التوازن في الشخصية مطلب إنساني وفطري وشرعي، ومبدأ تربوي إذ جاءت النصوص من الكتاب والسنة آمرة به محذرة مما سواه من الإفراط والتفريط. 
• إن الوسطية صفة الفطرة والمنهج الإسلامي في عقائده وتثريعاته، وهي الأنسب للإنسان، والخروج عنها ابتداع في الدين وخروج عن المنهج الرياني القويم.

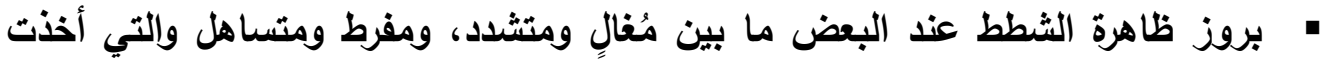
مجالات عدة سواء كانت في العقائد أو في السلوك والأخلاق، وهذا كله يحتاج إلى تأكيد مبلأ الوسطية في شخصية المسلم لكي تتضح معالمها في أذهان الناشئة.

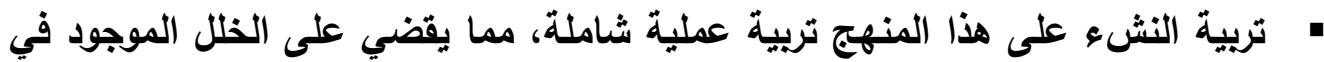
محيط المجتمع المسلم سواء أكان إفراطًا أو تفريطًا.

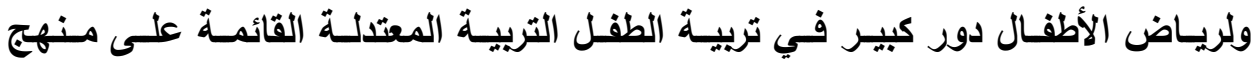
الوسطية من خلال تربية الطفل التربية الإيمانية، وترسيخ مبادئ الدين الإسلاهي حتى يكون لاى الطفل الوعي الكامل والفهم السليم للشريعة الإسلامية. • التربية الإيمانية لطفل الروضة: تعد التربيـة الإيمانية ضرورة للطفل لأنها تربط الطفل بالدين الإسـلاهي، ومن خلال التريبة الإيمانية يعرف الطقل أركان الإسلام، ويفهم مبادئ وأصول الثريعة الإسـلامية، وهي

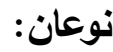
النوع الأول : التربية العقائدية ( غرس العقيدة الإسلامية في نفوس الأطفال ) :

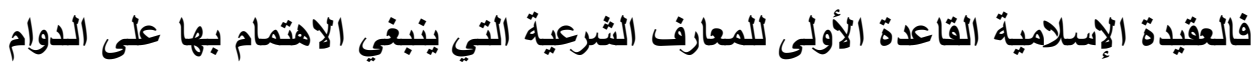
لأنها تحوي العلوم التي تقوم عليها حياة المسلمين أفرادًا وجماعات في كل عصر ، وعقيدة العادية

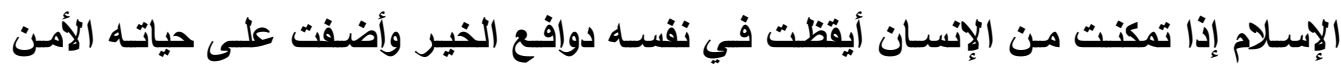
والطمأنينة وحمته من الثـك والارتياب، ومحت من نفسـه القلق والحيرة ولذلك هي الركيزة

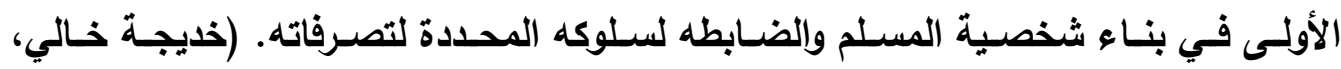
(rtritr وتثمل العقيدة الإسلامية الإيمان بالله وتوحيد ألوهيته وصفاته، والإيمان بالملائكة على آلئ نحو ما جاء بالكتاب والسنة، والإيمان بالكتب وأنها منزلة من عند الله، وأن القرآن حفظه الله اللهائه

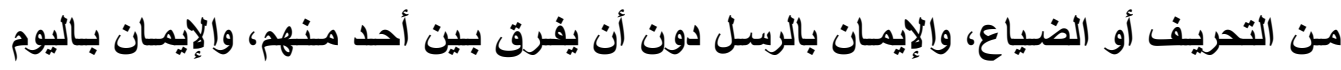

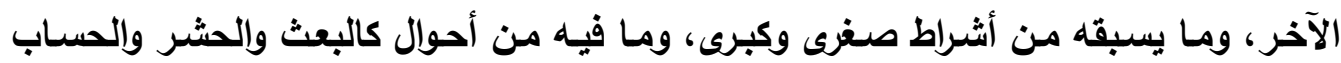


والصحف والموازين والصراط والشفاعة والجنة والنتار، والقلدر خيره وشره. (عمر بن الخطاب

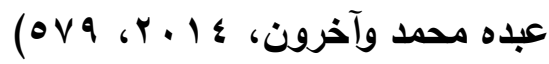

ولكي تقوم ريـاض الأطفـال بهذ الدور يجب أن يكون يكون المريـون والقائمون على

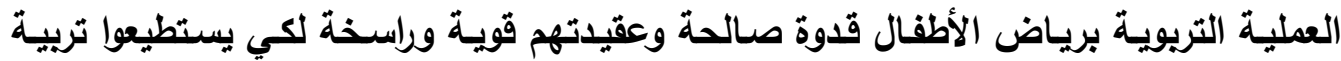
الأطفال التربية الإيمانية السليمة منذ نعومـة أظفارهم حتى يشبوا متسلحين بالإيمان، وللديهم الفهم واللوعي بمبادئ الشريعة الإسـلامية الغراء، ويطبقوا المنهج الوسطي في سـائر أقوالهم وأفعالهم وسلوكهم.

\section{• النوع الثاني : التربية العبادية ( تكامل العقيلة مع العبادة في تربية الطفل ) :} إن النواحي العباديـة هي الأمور المهمـة التي لابـد من أخذها بكل اهتمـام وجدية على طريق تكملة بنـاء الإنسـان المسلم، وتتم هذه الخطوة عن طريق المربين بأن يعودوا الطفل على ممارسة الأمور العبادية من صوم وصـلاة ومـا شـابه ذلك، واللغايـة من ذلتك تعويد الطفل وتمرينهله على فعل العبادات والطاعات، وإن لم يدرك الفائدة منها، والمنفعة المترتبـة عليها، فممارسته على فعلها مع تشجيعه تجعلها تصبح عادة لديه، فلا يصعب عليه متى كبر وشب أن يؤدي صلاته، وحتى تصبح الصلاة وما فيها من فائدة جزعًا من تفكيره وسلوكه. (مؤسسـة

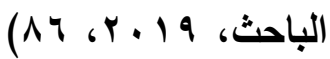

ويجب أن تقوم رياض الأطفال بتنشئة الطقل وتعويده على العبادات، وتدريبه من خلال

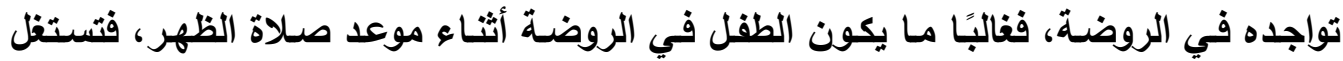

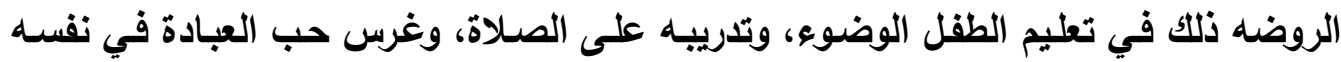
حتي ينشأ على الطاعة والعبودية لله عز وجل، فإذا ما تعود الطقل على أداء العبادة استقامت شخصيته وصلح عقله وأصبح محافظًا على إقامـة شعائر الدين الإسـلامي الحنيف بـلا تفريط ولا تهاون، ويذلك تتحقق التربية الوسطية للطفل من خلال البناء العبادي. كما أن تربية الطقل على العبادة الصحيحة التي شرعها الله تعالى تربية لهم على منهج الوسطية التي جاء بها الدين الإسلامي، ويُعد عن الغلو والتطرف، ومحاريـة للمفاهيم الباطلة والأفكار المنحرفة، وتحقيق للتوازن بين متطلبـات الفرد الماديـة والروحيـة بمـا يتفق وفطرتهـه السليمة التي فطره الله عليها. (عبد الرحمن عبد العزيز السديس، V V . Y، I I I) فيتحقق 
تربية الأطفال على الوسطية في الإسلام

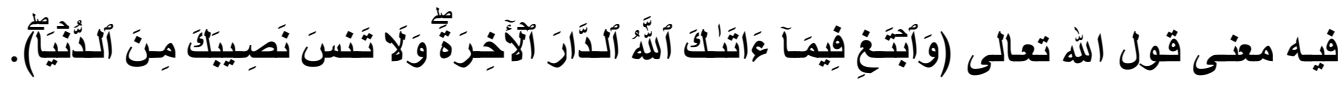
(سورة القصص: الآية (vV)

كما يمكن تحديد دور مؤسسات رياض الأطفال في تريبة الطقل على الوسطية من خلال ما يلي:

\section{تنثئة الأطفال على منهج الوسطية لبناء الشخصية الإسلامية المتوازنة.}

تعد تربيـة الطفل وتنشئته على الوسطية هي السبيل الوحيد والأكيد لبناء شخصيته

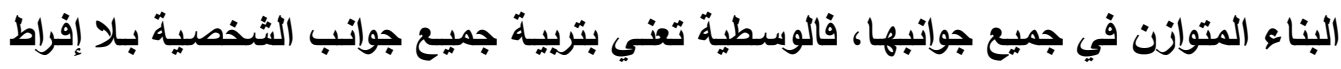

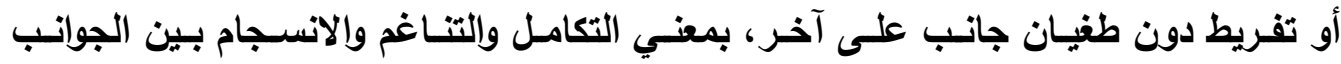
الجسمية، والروحية، والعقلية، والوجدانية، والاجتماعية.

فالتربية الوسطية الإسلامية تجمع بين تأديب النفس، وتثقيف العقل، وتقوية الجسم،

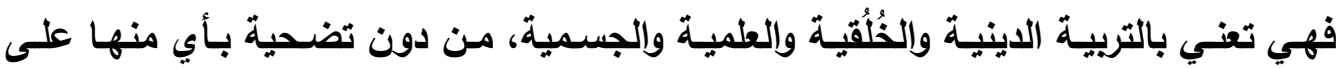

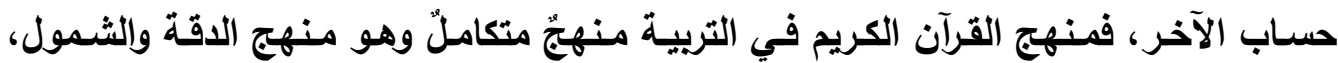

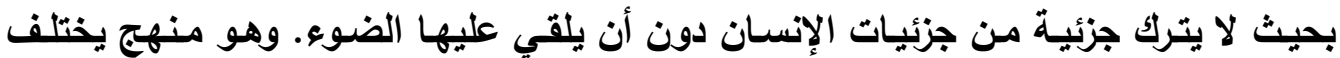

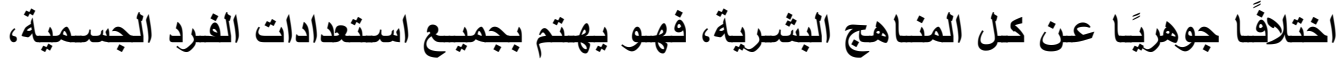

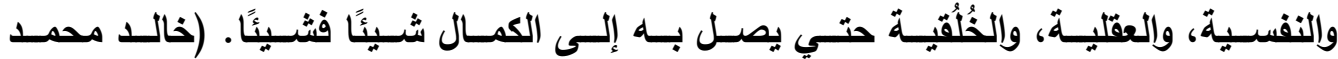

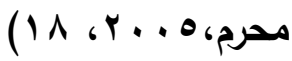

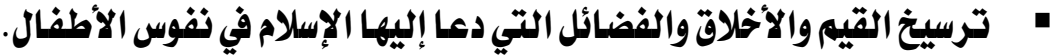

ينبغي أن تعـل ريـاض الأطفال على غرس القيم الأخلاقيـة، والفضـائل الإسـلامية في

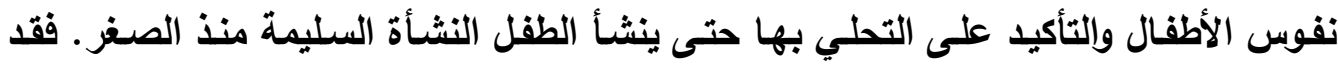

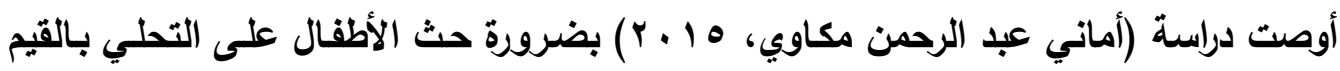

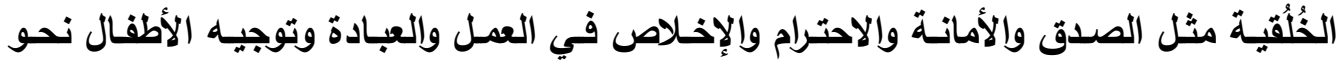

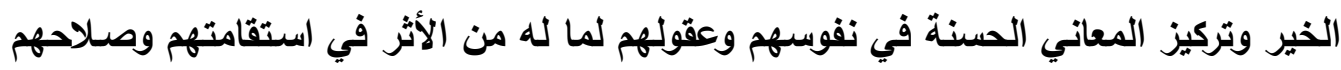

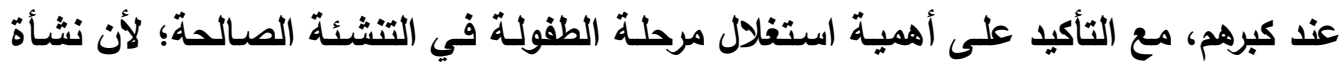
الصغير على شيء تجعله متطبعًا به، وما أغُفل في الصغر كان تأديبه في الكبر عسيرًا. فالأخلاق الإسلامية منبعثة عن العقيدة الإسلامية السمحاء التي تحدد للمسلم السلوك

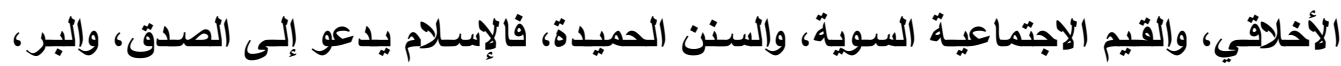




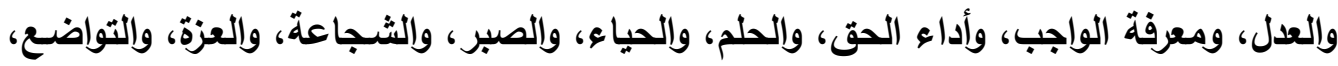

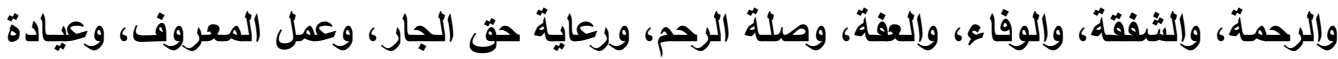

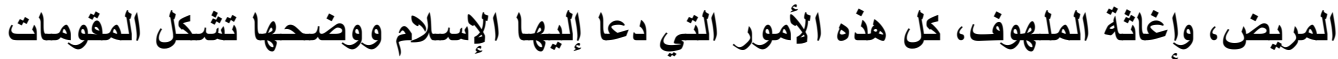

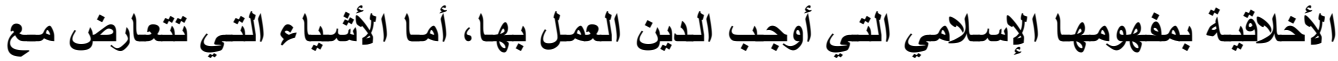

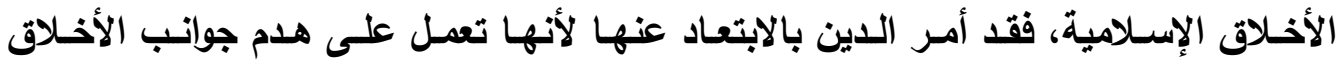

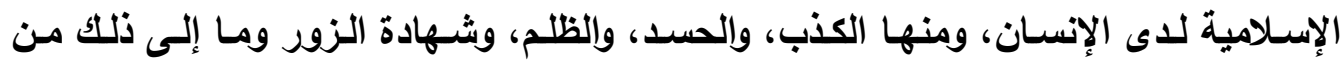
الأشياء الأميمة التي ينبغي على المسلم أن يتجنبها. (بلقيس إسماعيل داغستاني، 10 ــr،

\section{" اختيار المعلمات اللاتي يتسمز بالفكر الوسطي واستبعاد ذوات الفكر المتشدد والمتعصب، وأيضًا

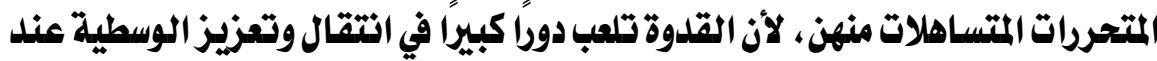

\section{الأطفال.}

فمعلمة رياض الأطفال هي أساس عملية التربية بالروضة ولها عظيم الأثر في نفوس الأطفال، فإذا كانت معلمة الروضـة تتسم بالوسطية سينعكس ذلك على الأطفال ويسهم في

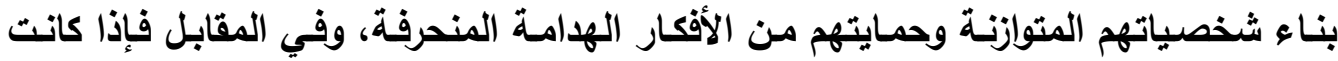

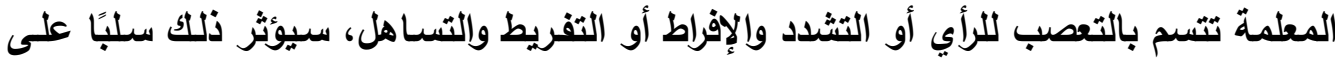
الأطفال ويتسبب في ظهور الكتير من المشكلات التريوية التي يعاني منها الطفل والمجتمع بالئح بأكمله، ومن هنا يجب الاهتمام باختيار المعلمة المناسبة.

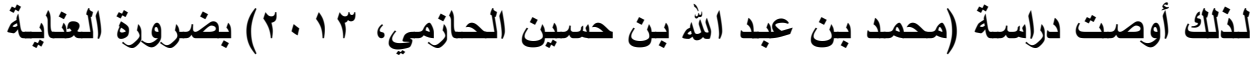

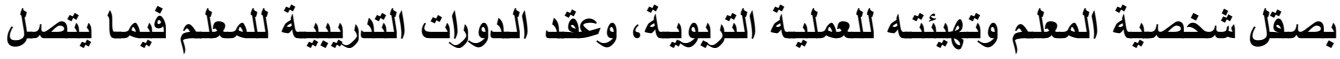

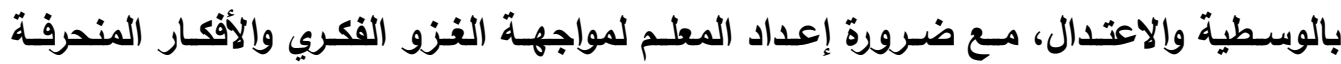
والمتطرفة وتوعيته بمبادئ الإسلام وقيمهـ. كما أوصت دراسة (فكري عبد المنعم السعدني،

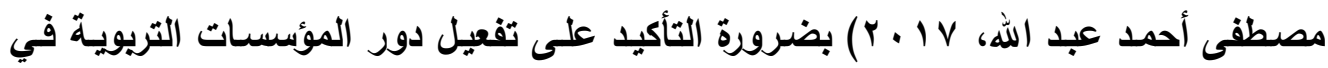

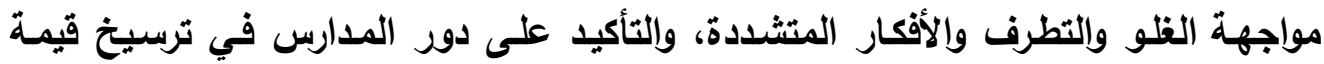

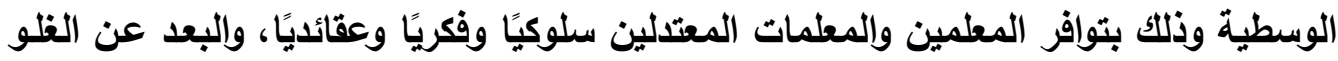
والتطرف والتعصب، ويتوافر المناهج التي تبعد عن الغلو والتطرف والتعصب، وإتاحة مزيد من الحرية للطلاب في التعبير عن أنفسهم. 
ولذلك فيجب أن يتم اختيار معلمـة ريـاض الأطفال المناسبة للعمل مـع الأطفـال والتـي تتسـم بالوسطية والاعتدال والبعد عن التشـدد، وأن تكون قدوة حسنة لأطفـال الروضـة في سلوكها وأخلاقها وأفعالها لمـا لها من أثر كبير في التأثثر على الأطفال وعلى معتقداتهم وأفكارهم.

• تربية الأطفال على قييم المحبة والإخاء والتسامح والتعاون والاحترام، ونبذ العنف والماجرات التي تؤدي إلى الكراهية والبُفض.

فالإسلام يدعو إلى السـلام والأمن ونبذ العنف والحرب وفي ذلك استقرار ورقي وتنمية

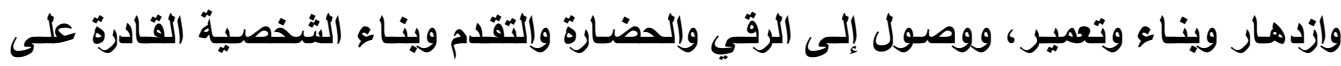
الابتكار والإبداع والاختراع وعبادة الله على الوجهه الأكمل، ويدعو إلى السـلام ونبذ العصبية

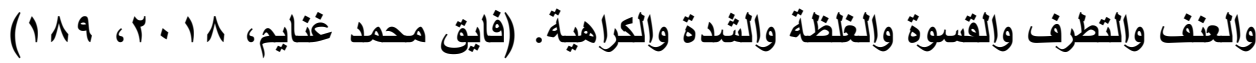

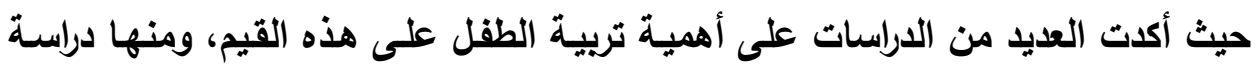

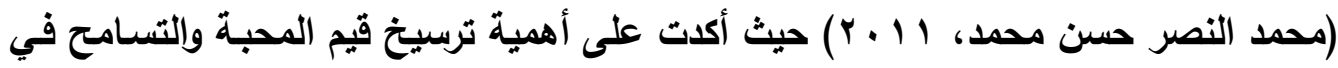

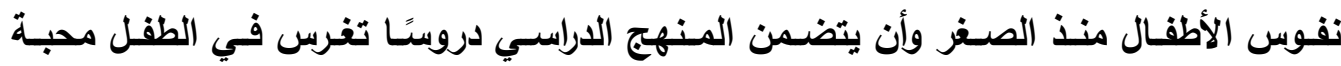

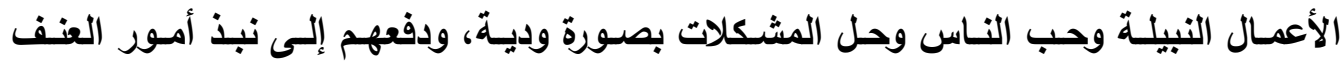
والتعصب، حيث إن تربية الأطفال على مثل هذه السلوكيات يضمن مجتمعًا خاليًا من أعمال العنف ويعيش في أمن وأمان.

• غرس وإعلاء قيمة الحوار في العملية التربوية بلدًا عن الأساليب القمعية التقليدية القائمة على التلقين وإعطاء الأوامر.

فالتربيـة القائمــة على القـع، والتتلقين، والسـيطرة وتخويـف الطفل، تـؤدي إلى تكوين وتخريج أجيال يغلب عليها الخوف، وضعف الثخصية، والاعتمـاد على الغير وعدم تحمل

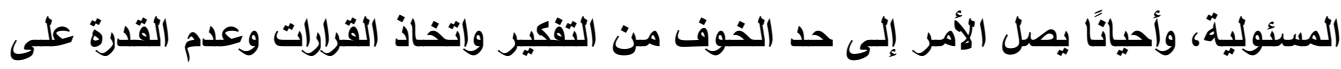
التعبير عن النفس والأراء، ولذلك لابد من غرس وإعلاء قيمة الحوار في العملية التريوية؛ لما له من آثار إيجابية في تكوين شخصية الطقل.

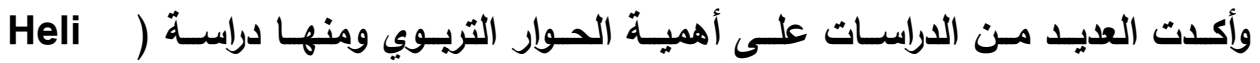
(Muhonen \& Others, 2020 والتعمق والفهم، وذلك من خـلال التفاعلات الاجتماعيـة التي يقوم بها المعلمون من خـلال 


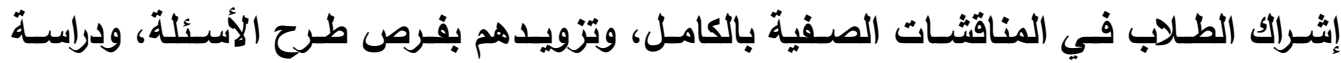
(Michael J. Baker, 2020) تسهيل التفاعلات بين الأطفال. كما أن التربية القائمة على الحوار وطرح الأسئلة والمناقثشة في رياض الأطفال تسمح

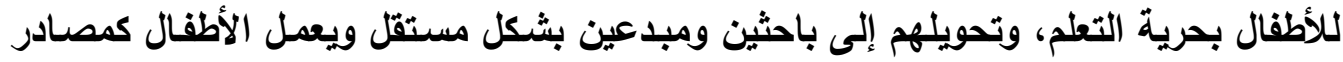
معرفة لبعهم البعض. (Molly Efrat, 2015, 174) ولذلك ينبغي تثجيع طقل الروضة على الحوار والمناقشـة مـع المعلمة، وأن يكون نظام

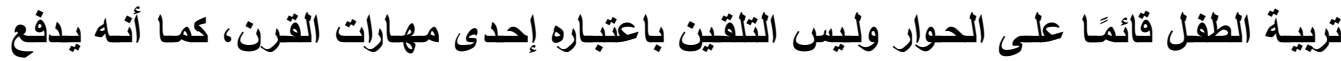
الطقل إلى التفكير النقاي والابتكاري، واتخاذ القزار وتحمل المسؤلية.

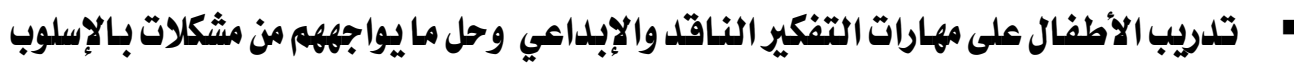
العلمي والمنهج السليه.

تعد مهارات التفكير الناقد وحل المشكلات مـن أهم الأسس الجديدة للتطلم في القرن الحادي والعشرين، كما تعد القدرة على التفكير الناقد أحد المهام الأساسية للتربية، الأمر الذي الذي التهاتي

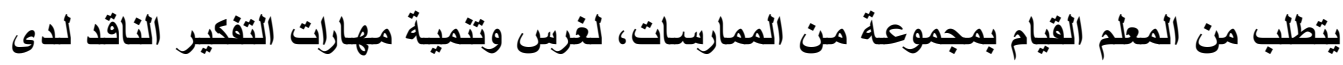

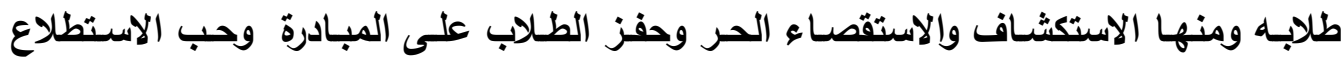

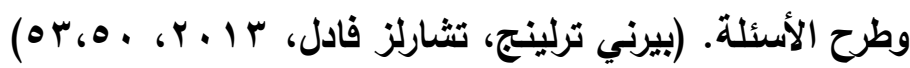
فمهارة التفكير النقدي هي المهارة التي تمكن الأطفال من تعلم كيفية حل المشكلات.

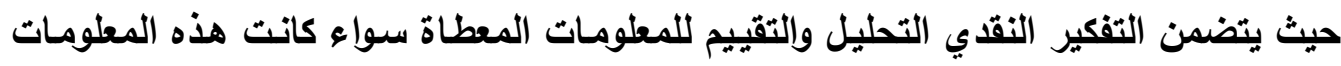
نتيجة الملاحظة، أو التواصل أو التجرية، كما أن التفكير الناقد من الوسائل المفيدة في اتخاذ

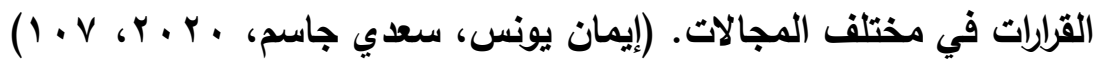

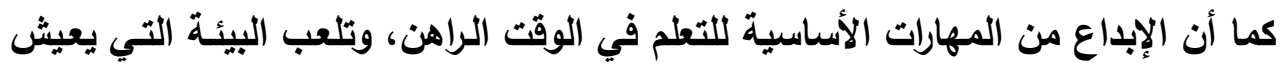

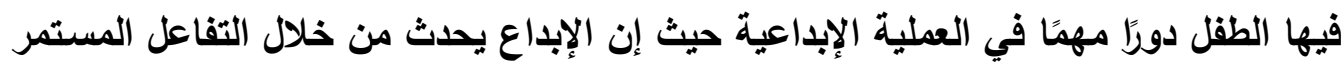

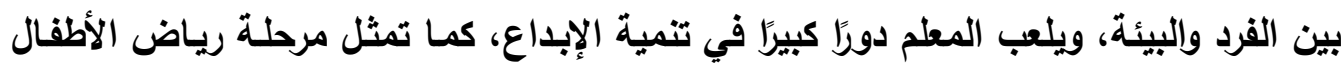

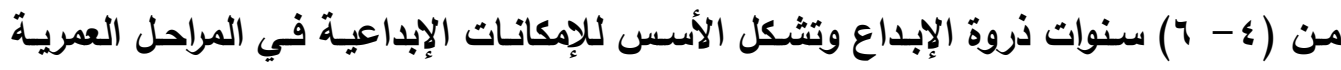
(Elisa Kupers \& Others, 2019, 99)( اللاحقة.)، 
ولذلك ينبغي تدريب الطقل على مهارات التفكير الناقد، والتفكير الإبداعي باعتبارهما من

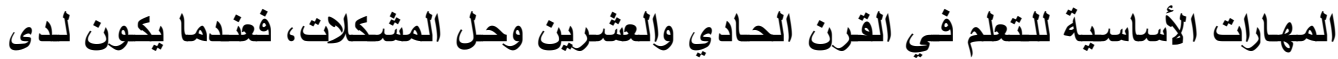
الطقل القدرة على امتلاك تلك المهارات؛ يستطيع التمييز بين الغت والثمين بين الخير والثر بين التفريط والإفراط، ويالتالي يجب أن تهتم رياض الأطفال بتعزيز تلك المهارات لدى طفل الروضة.

\section{ثالثًا : التطبيقات التربوية للوسطية في ريساض الأطفال:}

يتم تطبيق الوسطية في رياض الأطفال من خلال عناصر المنظومـة التريويـة بأكملها

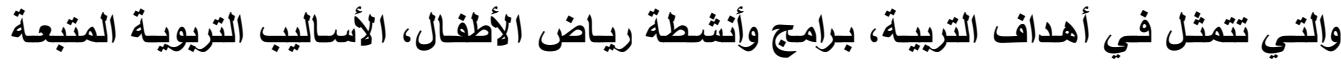
لتربية طقل الروضة، معلمة الروضة.

\section{1. التطبيقات التربوية للوسطية في أهداف التربية ؛}

تعد مرحلة رياض الأطفال مرحلة تريويـة لها فلسفتها وأهميتها التي تميزها عن غيرها من المراحل لأنها تتعامل مع مرحلة متميزة وخاصة وهي مرحلة الطفولة أساس بناء الإنسان،

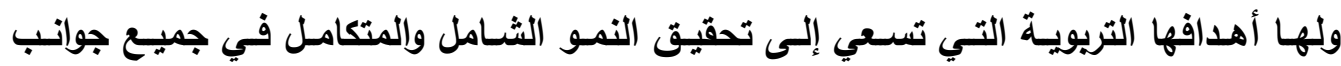
شخصية الطفل، وتعد الأهداف التربوية هي الأساس الذي تقوم عليه عملية التربية بأكملها. ويمكن تلخيص أهم أهداف التربية في رياض الأطفال في النقاط الآتية:(محمد كمال يوسف، التهيه $(\leqslant \wedge, r+\cdots q$

• التنميـة الثـاملة للأطفـال فـي المجـالات العقليـة والجسـمية والوجدانيـة والاجتماعيـة والانفعالية. • • الاهتمام بالجوانب الدينية والخلقية للطقل. • التشـئة الاجتماعيـة والصحية السليمة للطفل في ظل قيم المجتمـع ومبادئهـ وأهدافه، وتنمية الاتجاهات الإيجابية نحو البيئة والمجتمع. • تلبية حاجات ومطالب النمو الخاصة بأطفال هذه المرحلة. • توثيق العلاقة بين الروضة والأسرة لاعم نمو الطقل وحل مشكلاته.

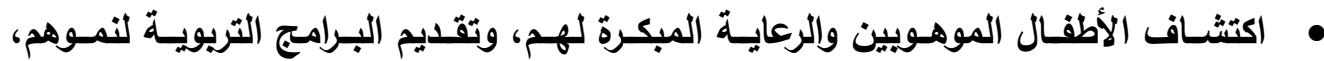
وتوجيههم للمراكز المتخصصة لتنمية مواهبهم وقدراتهم. 
• تهيئة الطقل للحياة المدرسية النظامية في مرحلة التعليم الأساسي، والانتقال التدريجي

$$
\text { من البيت إلى المدرسة. }
$$

تزويد الأطفال بالمهارات الأساسية، وتنمية استعدادهم للقراءة والكتابة والحساب. • تنمية مهارات الأطفال القنية والعلمية من خلال اللعب والنشاط. ويمكن تطبيق منهج الوسطية من خلال أهداف التربية التي تسعى رياض الأطفال إلى تحقيقها، وجعل الوسطية هدف تريوي من تلك الأهداف لغرسـه في نفوس الأطفال لمـا لـه من أهمية في تكوين شخصية الطفل والمواطن الصالح المتزن. وفيما بلي أهم التطيقات التريوية للوسطية في أهداف التربية في رياض الأطفال. - - أن تسعى أهداف التربية إلى غرس الوسطية في نفوس الأطفال، وذلك من خلال تمكينهم وتعريفهم بمبادئ الدين الإسلامي الحنيف، والعقيدة الإسلامية الصحيحة. - أن تعمل على إكساب الأطفال لمبدأ ومنهج الوسطية في أقوالهم وأفعالهم وسلوكهم. - أن تعمل على توعية الأطفال بمبدأ الوسطية وأهمية تطبيقه في الحياة وما يعود على العيه الإنسان من خير نتيجة اتباع المنهج الوسطي الإسلامي.

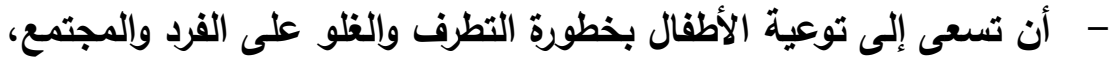
والمشكلات التي قد تحدث للإنسان نتيجة بعده عن الوسطية. - - أن تؤكد على غرس القيم والفضائل الإسلامية في نفوس الأطفال، وضرورة تنشئتهم التشئة الاينية السليمة.

\section{r. r. التطبيقات التربوية للوسطية في جوانب تربية الطفل :}

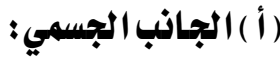

يعد الجانب الجسمي من جوانب النمو المهمة، والذذي يؤئر بثكل مباشـر على بقية الجوانب الأخرى، كـالنمو اللغوي والمعرفي والاجتمـاعي والانفعـالي، لذا يتوجب على ريـاض الأطفال أن تولي الاهتمام الكافِي بهذا الجانب من جوانب النمو عن طريق توفير المستلزمات

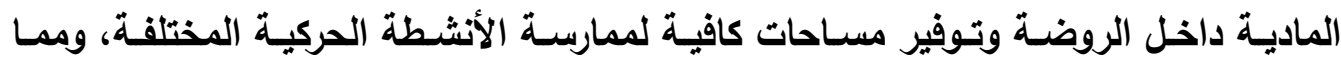
يسـاعد على النمـو الصـحيح والسـوي للجسـم الرعايـة الصـحية والطبيـة للأطفـال مـن خـلال المحافظة على ممارسـة السـلوكيات الطبيـة الصـحية مثـل: الاعتــال في تتـاول المشـرويات 
والأطعمـة، والنـوم مبكرًا، وممارسـة التمـارين الرياضية، والاهتمـام بالنظافـة الثخصية. (نـافز

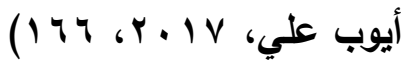

واهتم الإســلام بالتربيـة الجسـمية والصـحية، وينـاء الجسـم القوي مـن خـلال الإثـباع المعتل، والوسطية في المأكل والمشرب والنوم، ولم تقف موقف الكبت أو قمـع مطالب الجسم المختلفة، وإنما إثباعها بشكل معتدل يتماشي مع آداب الإسلام في تربية الإنسان، ويما أمر

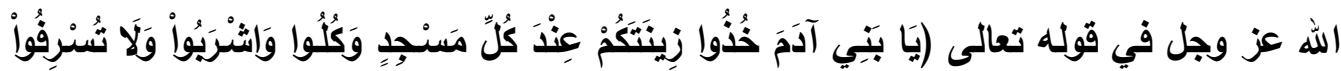

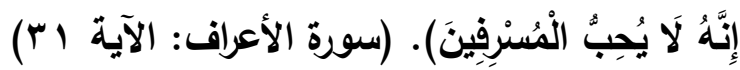

ولرعاية الجانب الجسمي ينبغي التوسط في تحقيق مطالبه كالوسطية في إثباع الجوع والعطش، والوسطية في النوم، وأحل الإسـلام للإنسـان الأكل والثـرب وحرم أن يُلحق الإنسـان الضرر بجسمه ويدنه كأن يمتنع عن الطعام، وأيضًا نادى بعدم الإسراف في الأكل والثرب، فلا إفراط ولا تفريط وذلك حتى يستقيم جسم الإنسان ويصبح قويًا بعيدًا عن العلل والأمراض.

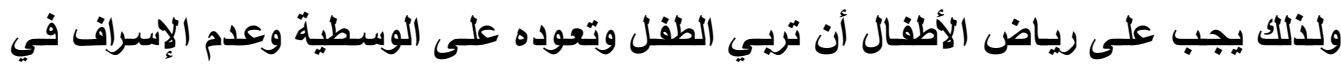
تحقيق مطالب نموه الجسمي.

ومن أهم التطبيقات التربوية للوسطية في الجانب الجسمي والصحي ما يأتي: - تريبة الأطفال على عدم الإسراف في الأكل والثرب والنوم والراحة، والتوسط في ذلتك حتى لا يصاب الإنسان بالأمراض. - - تربية الأطفال على الاقتصاد وعدم الإسراف والتبذير في الإنفاق وشراء كل مـا تشتهي

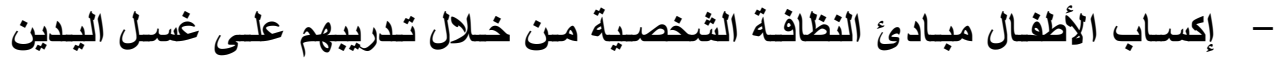
والوضوي، ونظافة المأكل والمشرب والملبس والمكان، فالنظافة من الإيمان كما أنها تحمي الجسم من الأمراض المختلفة.

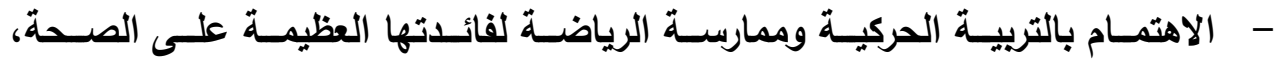

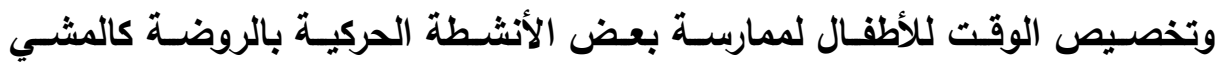
والجري والوثب والقفز وغيرها من التمرينات والأنشطة المختلفة. - - عدم الإفراط في اللعب حتى لا يصاب الأطفال بالتعب والإجهاد. - - ضرورة التدرج في التمرينات المقدمة للأطفال من السهلة إلى الصعبة. 
- -

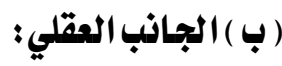

يعد الجانب العقلي من الجوانب المهمـة التي يجب الاهتمـام بها، وتربيته منذ مرحلة الطفولة حتي يكون الطفل قادرًا على التفكير الجيد السليم المبني على المنهج العلمي، وقادرًا - أيضًا - على التفكير النقاي والإبداعي ولا يتم ذلتك إلا من خلال عملية التربية التي تعود الطقل وتكسبه أنماط التفكير المختلفة. والتربية العقلية هي تكوين فكر الطقل بكل ما هو نافع من العلوم الدينية والثقافة العلمية والعصرية والتوعية الفكرية والعضارية حتي ينضج فكريًا، ويتكون علميًا وثقافيًا.

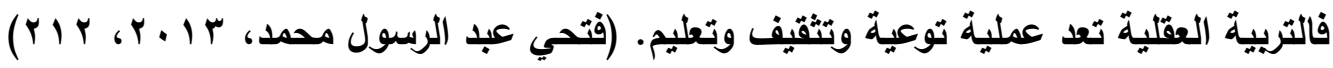
وتعد مرحلة ما قبل المدرسة مرحلة السؤال والاستفسار والاستطلاع والبحث. ويتميز الطقل بقوة خياله وولعه باللعب وتمثيل الأدوار، ويقع على عاتق رياض الأطفال مسئولية كبرى في العمل على زيادة النمو العقلي عند الأطفال وذلك من خلال العمل على توفير مثيرات متنوعة واسعة للطفل عن طريق اصطحابه في نزهات ورحلات جماعية، والعمل على تثجيع وتنمية هوايات الطفل المختلفة مثل جمع الصور والطوابع، وتثجيع ألعاب تمثيل الدور المعتمدة على الخيال، وفتح أطر التواصل اللفظي والحوار مع الأطفال. كما يحتاج الطقل في هي هذه المرحلة إلى تنمية المهارات العقلية مثل التذكر، الإدراك، التفكير، ولابد من تربية حواس التراس الطقل مع تدريبه على الملاحظة المنظمة، وتتويع خبرات الطفل الفردية، حتى يكتسب خبرة

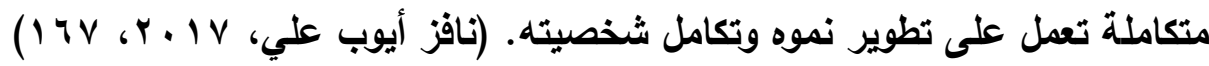
واهتم الإسلام بالتربية العقلية للطقل من خلال تنمية ذكائه وقدرته على التفكير والتأمل والتحليل، فالتربية العقلية للطقل تهتم بتثبيت العقيدة في نفس الطقل وتعريفه بالإسلام، ويدون التربية العقلية يختل بناء الثخصية المتوازنة، ولذلك أولى الإسلام عناية كبيرة للعقل والتربية العقلية.

ومن أهم التطبقات التريوية للوسطية في الجانب العقلي والفكري ما بأتي:

- - تدريب الأطفال على التفكير الناقد والتفكير الإبداعي وإعطاؤهم الثقة بأنفسهم. - - تثجيع الأطفال على الحوار، واحترام آراء الآخرين وعدم التشبث بالرأي، واستخدام الإقناع. 
- - تلريب الأطفال على التفكير المنطقي القائم على الأدلة والبعد عن الظن والتخمين. - تعويد الأطفال على إبداء الرأي ورفض التقليد الأعمى دون فهم وتدبر. - - تدريب الأطفال على الانتقاء والتمييز بين الجيا والردئ، وخاصة فيما يشاهدونه من أفلام ويرامج الكارتون المسمومة التي تروج للعنف والتعصب وإيذاء الآخرين. - - تعديل السلوكيات الخاطئة عند الأطفال.

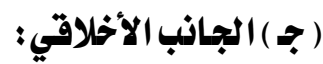

تعد التربية الأخلاقية أحد جوانب التربية المهمة والتي يجب أن يهتم بها المربون لما

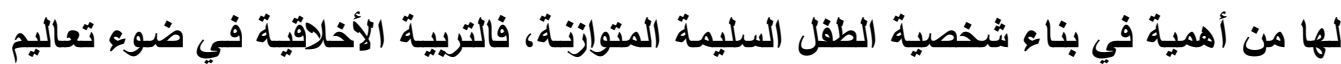

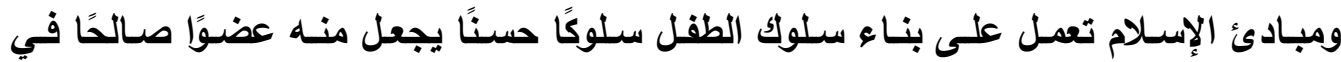
المجتمع وتحمي الطفل من الوقوع في الشرور والتطرف والانحراف، وتحقق الاستقرار والأمـان على المستوى الثخصي والاجتماعي. فالتربية الخُلُقية هي روح التربية الإسلامية والوصول إلى الخلق الكامل هو الغرض

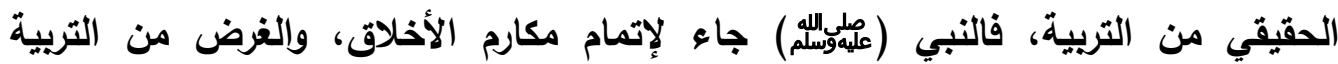
الإسلامية الأخلاقية يكون بالعمل على تهذيب الأخلاق وتأصيل القيم. ويؤكد المنهج الإسلامي على الأهمية القصوى للمعلمين في الاقتداء بسيد الرساية وخاتم النبيين بأخلاق الرسول

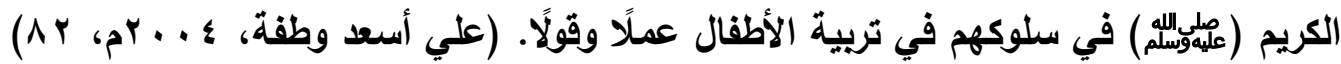

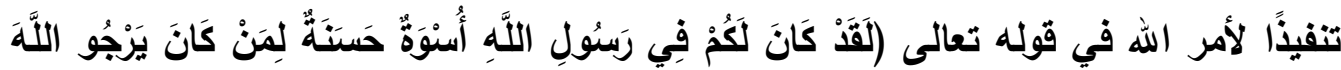

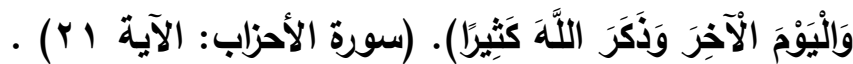

\section{ومن أهم التطبقات التربوية للوسطية في الجانب الأخلاقي ما بأتي:}

- غرس القيم الإسلامية الأصيلة في نفوس، الأطفال وإكسابهم الفضائل الأخلاقية. - - الابتعاد عن الرذائل الأخلاقية كالكذب والسرقة واللنميمة والسخرية من الآخرين وغيرها. - - الاقتداء بالنبي (علئسلالم) في أخلاقه الطيبة وسلوكه وإرشاداته، ووسطيته المحمودة. - تعبيب الخير إلى نفوس الأطفال، ويغض الثرور والابتعاد عنها لأنها تغضب الله عز وجل. - تحفيظ الأطفال بعض الأحاديث النبوية الثريفة التي يمكنهم فهمها والتي تنمي في نفوسهم القيم الدينية والأخلاقية كمساعدة المحتاج، وكف الأذى عن الطريق، وير 
الوالدين، وصلة الرحم، وحسن الجيرة، واحترام الكبير، والرحمة، والرفق بالحيوان، وغيرها من القيم الإسدلامية.

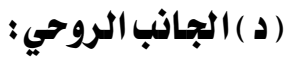

ويقصـد بالتربيـة الروحيـة غرس الإيمـان في نفوس الأطفـال إتباعًا لنـزعتهم الفطريـة للتدين، وتهذيب غرائزهم والسمو بنزعاتهم، وتوجيه سلوكهم على أسـاس القيم الروحية التي تستمد من الإيمان الصحيح بالله عز وجل وملائكته وكتبه ورسله واليوم الآخر والقدر خيره

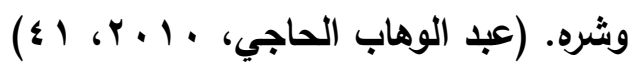

فالإيمـان بـالله هو الركن الأول من أركان الإيمان، ويجب أن يُريسى الطفل منذ الصغر

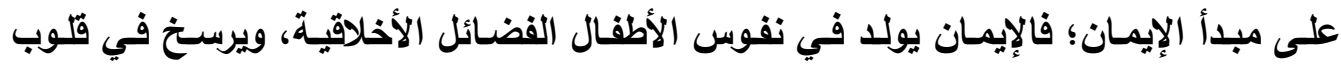
الأطفال المعاني والأسس الإسلامية، كما يدفع الطفل إلى طاعة الله وإبتغاء مرضاته والخوف من غضبه. ويناء عقيدة قوية لاى الطفل تبدأ من الإيمان بالله ثم ملائكته، وكتبه، ورسله واليوم

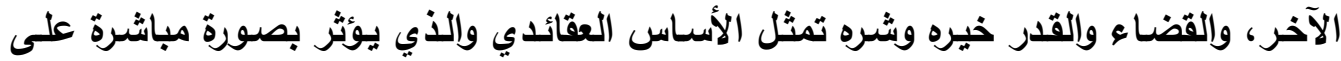
باقي الأسس ويشكل كبير جدًا وينبثق عن هذا الأسـاس أسـاس تعبدي يتمثل في تطبيق الأساس العقائدي واقعيًا من خلال مظاهر الحياة الدينية والاجتماعية والكونية وإلتي تتكامل فيما بينها بشكل رائع ومتميز يعكس عمق الأساس التعبدي في التربية والتي تستقي جوهرها

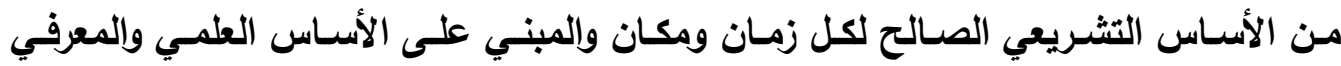

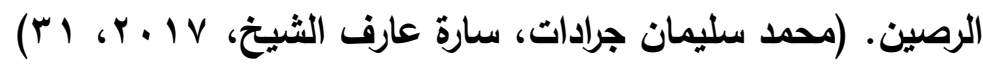
ومن أهم التطبيقات التريوية للوسطية في الجانب الروحي ما يأتي:

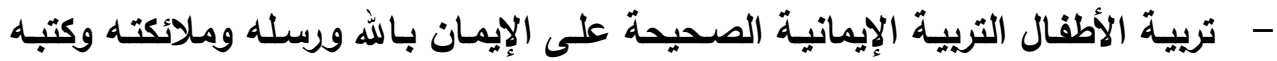
والقضاء والقدر خيره وشره. - - تعليم الأطفال القرآن الكريم، وتحفيظهم مـا تيسر من بعض السور القصيرة والآيات التي يمكنهم فهمها. - - تأصيل محبة النبي الكريم عليه أفضل الصـلاة والسـلام في نفوس الأطفال والاقتداء

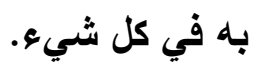

- - تعريف الأطفال بأركان الإسلام وأداء الفروض كالصلاة والصوم والزكاة والحج. 


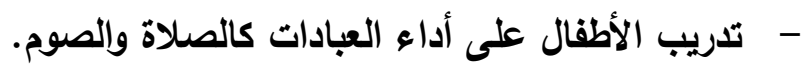
- - تعويد الأطفال على مراقبة الله عز وجل في أقوالهم وأفعالهم. - - تحفيظ الأطفال بعض الأدعية البسيطة كدعاء ما قبل الأكل، ودخول المنزل والخروج منه، والركوب، والنوم والاستيقاظ، وغيرها من الأدعية التي تتناسب وعمر الأطفال.

$$
\text { الجانب الاجتماعي والوجداني ( الانفعالي )؛ }
$$

ويقصد بالوجدان جميع العواطف والمشاعر والأحاسيس والانفعالات النفسية التي ينبني عليها سلوك الفرد، وتتبلور على مستوى مواقفه واتجاهاتهـه ومعاملاتهـ وأخلاقه، وتؤثثر عليها بشكل مباشر . ومن أهم جوانب التربية في الجانب الوجداني التي اهتم بها الإسـلام واهتمت ماته

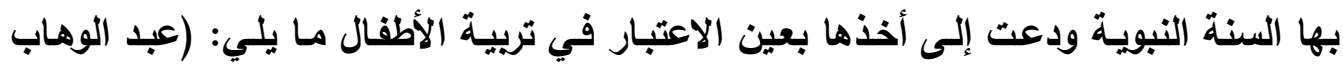

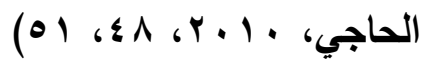
- - الدعوة إلى ضبط النفس أثناء الغضب.

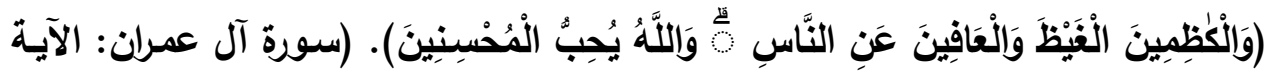

- الدعوة إلى المودة والتسامح وحسن المعاملة - - النهي عن الاتصاف بالغرور والكبرياء

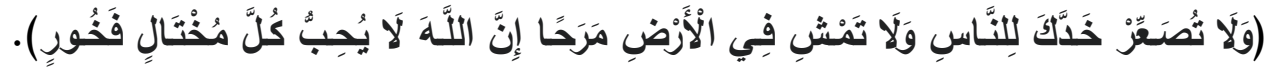

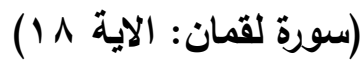
- - عدم الاستسلام للخوف أو البكاء. - - الدعوة إلى تنمية الاستقلال العاطفي في اتخاذ المواقف الإيجابية. - - الدعوة إلى عدم بناء المواقف على الظن والأفكار المسبقة.

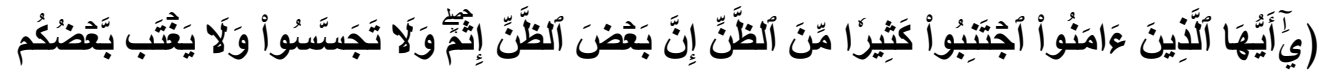

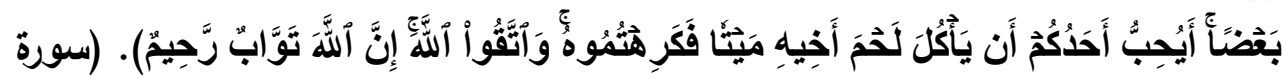

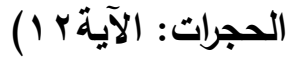

كما تتميز مرحلة مـا قبل المدرسـة في النمو الاجتمـاعي والانفعالي الوجداني بـالعنف،

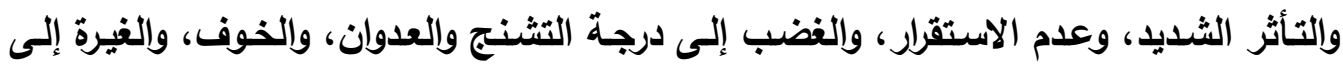


درجة التحطيم، وإلحزن إلى درجة الاكتئاب، وأيضًا حالة التذبذب بين الألم إلى السـعادة، ومن

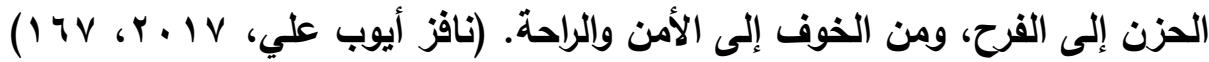

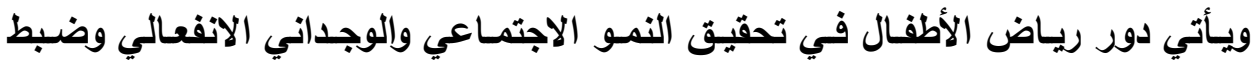
انفعـالات الأطفـال ومسـاعلتهم على الـتخلص مسن المشــاعر السـلبية، وإكسـابهم المعـايير الأخلاقية والقيم الاجتماعية من خلال عملية التنشئة وإلتطبيع الاجتماعي للطفل حسب ثقافة المجتمع الأي يعيش فيه. ومن أهم التطبيقات التربوية للوسطية في الجانب الاجتماعي والوجداني (الانفعالي) مـا - سـرد القصص والحكايـات التي تجسد القيم الاجتماعيـة والوجدانيـة الصـالحة، ويخاصـة قصص الصحابة والمرسلين والسلف الصالح. - - مساعدة الأطفال على التخلص من النزعة الأنانية وإلتمركز حول الأات. - تدريب الأطفال على تحمل المسئولية والاستقلالية وتكوين الفكر النقدي. - - تهذيب وضبط انفعالات الأطفال وإلتخلص من الانفعالات السلبية. - - تنمية قرة الأطفال على احترام الآخرين وتقدير مشاعرهم وعدم إيذائهم بالقول أو الفعل. - غرس قيم الإسـلام السـحة في نفوس الأطفال كالتسـامح، والتعاون، والإيثار، وآداب الاختلاف، وآداب الحوار وإلحديث. - تعويد الأطفال على الآداب الاجتماعية المختلفة، كآداب الطعام والشراب، وآداب الحديث، وآداب الاستماع، وآداب الزيارة وغيرها من الآداب. - - تحفيظ الأطفال بعض الآيـات القرآنية والأحاديث النبويـة التي تخص التص الجانب الاجتمـاعي والوجداني، وسرد مواقف الرسول (عليهوسلمه) على مسامع الأطفال حتى يقتدوا به. r.r.التطبيقات التربوية للوسطية في منهج رياض الأطفال: يقصد بالمنهج كل مـا تقدمه الروضـة إلى أطفالها لتحقيق الأهداف التريويـة، ويشتمل على بعض المفـاهيم والمعلومـات والحقائق مـن أجل تكوين شخصية الطفل وتتميـة قدراتهـ المختلفة، وأيضًا الخبرات المتعددة التي يكتسبها الطفل مما يؤدي إلى النمـو الثـامل المتكامل في جواتب شخصيته. 


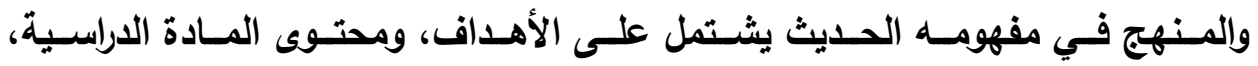
والأنشطة، واستراتيجيات التدريس، وطرقه وأساليبه، والوسائل التعليمية، ودور المعلم، وعملية التقويم. والمنهج هو برنامج أو نشاط يدل على التطليم، وهو كل عمل منظم يمارسه الطفل

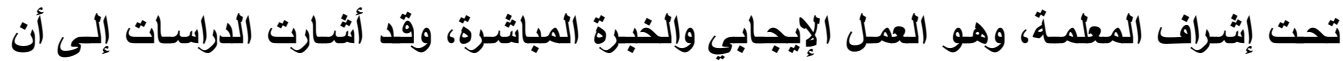
المنهج الدراسي المميز الذي يصلح للتطبيق على أطفال مـا قبل المدرسة هو المنهج المبني

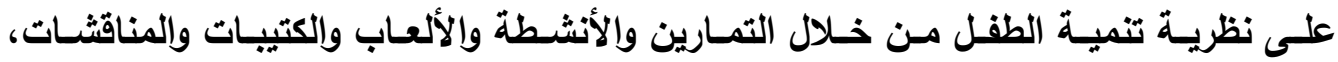
وتحتوي موضوعات هذا المنهج على القطع الخشبية واللعب في أحد الأركان بحجرة النشاط،

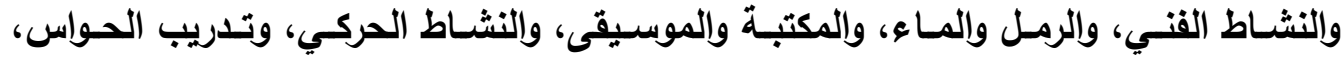

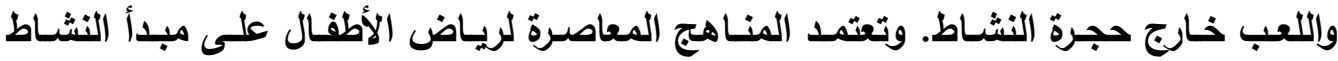

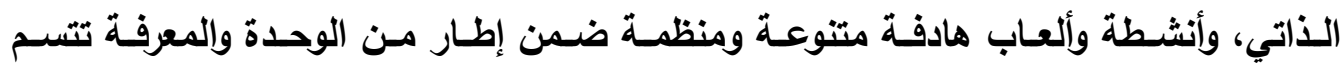

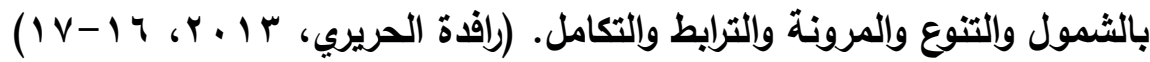
وتقوم رياض الأطفال على أسـاس منهج مرن، وليس لها مواد ثابتة معينة، والمبدأ الذي يقوم عليه المنهج هو التعلم عن طريق العمل، ويراعى في تخطيطه أن يوجه الاهتمام

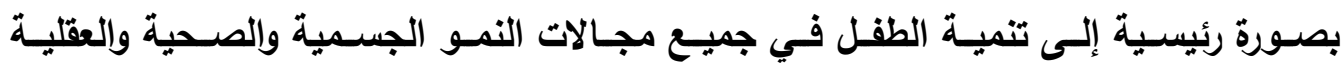
والاجتماعية والانفعالية والروحية، وينبغي أن يكون سلسلة من النشاطات الهادفة إلى تنمية

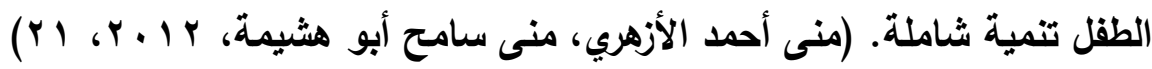

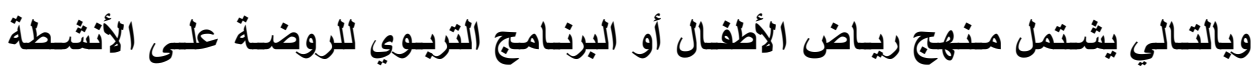

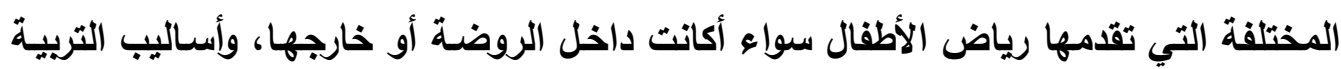

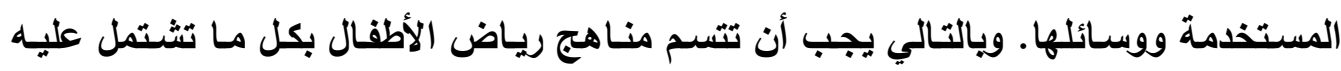
بالوسطية لتكوين شخصية الطفل المتزنة في جميع جوانبها.

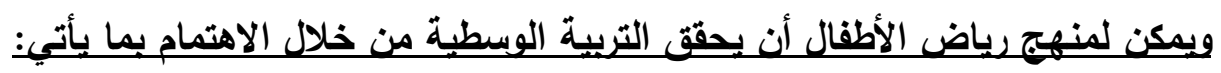

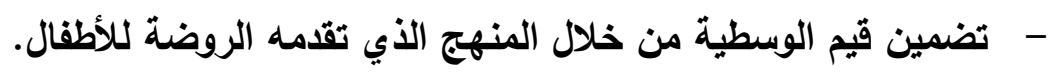

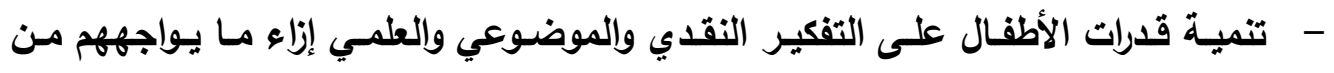
مشكلات، وإكسابهم مهارات التفكير المختلفة. - - اشتقاق منهج رياض الأطفال من المجتمع ذاته وأن يكون مرتبطًا به ويقضاياه المتعددة، وأن يعمل على غرس وتحقيق الوسطية التي يحتاج إليها المجتمع. 
- أن يتم تطوير تلك المناهج لمواكبة التغيرات المتلاحقة التي يفرضها التغير في العالم المعاصر في شتى المجالات.

- أن يعمل على تنمية القيم والفضـائل الأخلاقية، وإكساب قيم وثقافة المجتمع الإيجابية التي تدعو إلى المحبة والتعاون والتسامح والتعايش السلمي واحترام الآخرين لتحقيق

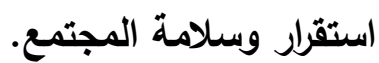
- استبعاد أي جزئيات أو موضوعات من المنهج قد تنمي في نفوس الأطفال بشكل صريح أو ضمني معاني التطرف والانحراف الفكري أو تدعو إلى العنف والعدوان. - - أن يسهم في ريط الطقل بوطنه وتعزيز قيم الاتتماء الوطني والديني والاجتماعي.

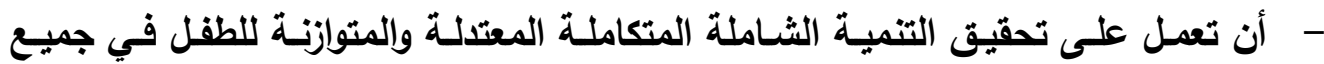
جوانب شخصيته دون إفراط أو تفريط. ؛. التطبيقات التربوية للوسطية في أنثطة رياض الأطفال:

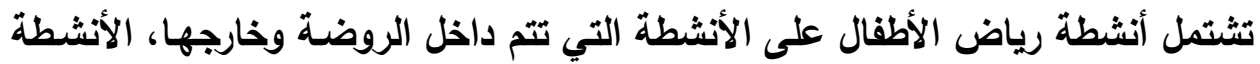

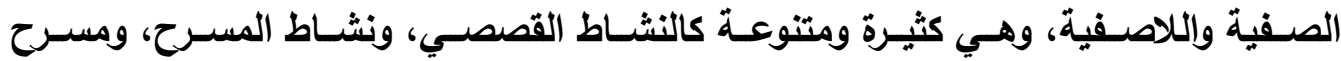
العرائس، والنشـاط الفني، والموسيقي وغيرهـا، ويمكن تطبيق الوسطية من خـلال الأنثطة التريوية في رياض الأطفال كالتالي:

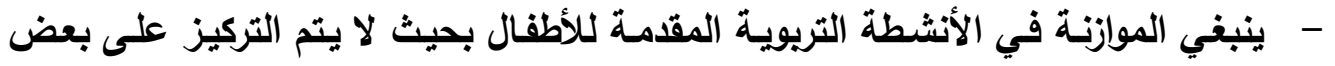
منها دون الأخرى، فلا يطغى جانب على آخر لتحقيق الثخصية المتوازنة للطفل.

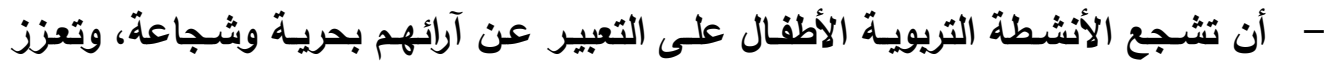

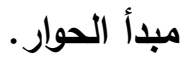
- أن تهتم الأنثطة بتوعية الأطفال التوعية الصحيحة بالوسطية الإسلامية ونثر الوعي

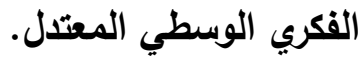
- أن تعدل هذه الأنثطة على غرس القيم الإيجابية التي تسعى التريبة الإسلامية إلى الى غرسها في نفوس الأطفال، وتسعى رياض الأطفال إلى تحقيقها. - - أن يتم ريط هذه الأنثطة بقضايا المجتمع المهمة، والمناسبات الاجتماعية حتي يكون الاطئ لاى الأطفال الوعي بما يدور بمجتمعهم ويتفاعلون معها. 
- يكن استغلال النشـاط القصصي في سـرد القصص التريويـة التي تؤكلد على منهـج الوسطية وخاصة القصص الإسلامية، وقصص السبرة النبوية. - عمل المسرحيات التي تتناول قيم الوسطية وعرضها على خشبة المسرح، أو من خلال مسرح العرائس.

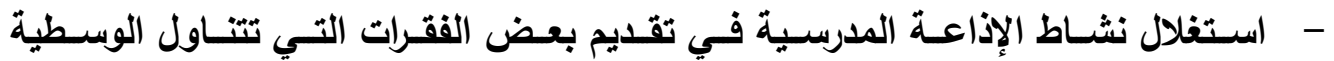
الإسلامية، مثل أناثيد الأطفال وأدبهم. - - أن تراعي هذه الأنثطة مستويات الأطفال العمريـة والعقلية وميولهم ورغباتهم حتى تحقق الهاف منها وإكساب الأطفال الوسطية الإسلامية. 0. التطبيقات التربوية للوسطية في أساليب التربية برياض الأطفال:

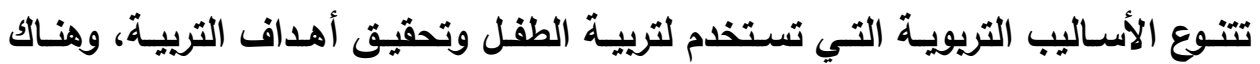
الكثير من الأساليب التريوية التي يمكن تعزيز الوسطية من خلالها، كأسلوب التربية بالقدوة الحسنة، والتربية بالثواب والعقاب، والتربية بالقصة.

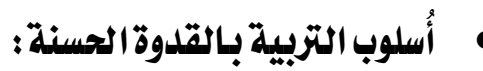

القدوة هي أفضل وسـائل التربيـة على الإطلاق وأقربها إلى النجـاح، ويعتبر الإسـلام

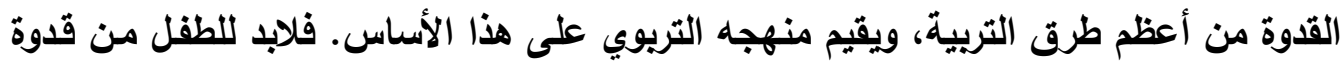

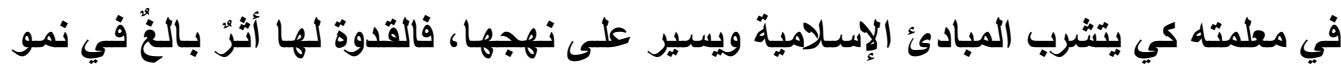

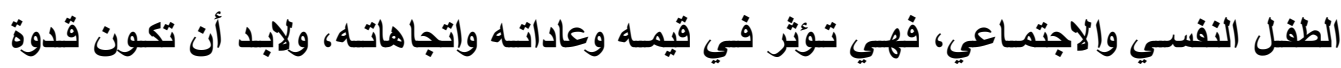

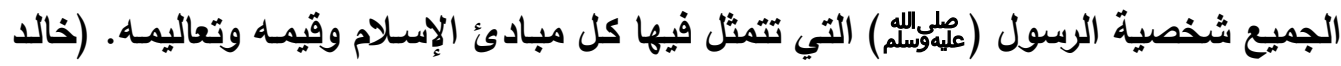

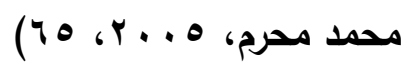
كما أن الأطفال بطبيعتهم يميلون إلى التقليد والمحاكاة، ومـن هذا المنطلق يجب أن تكون مطلمة رياض الأطفال قدوة طيبة ونموذجًا صالحًا للتقليد يُحتذي به في تحليها بالصفات الصات الحميدة، والفضائل الأخلاقية وفي كل شيء، وتعد القدوة أهم أسلوب تربوي وأكثرها تأثيرًاً في

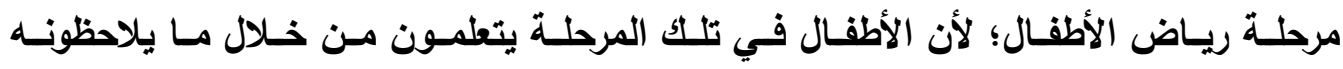
ويثاهدونه بأعينهم، ولذلك أكد الإسلام على ضرورة أن يكون المربي قدوة حسنة. وقد تناولت دراسة (Maizura Yasin \& Others, 2020) أدوار المعلم والتحديات

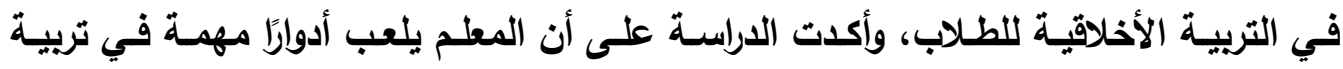


الطلاب التربيـة الأخلاقية وكثفت الدراسـة عن سبعة أدوار يقوم بها المعلم في هذا المجال

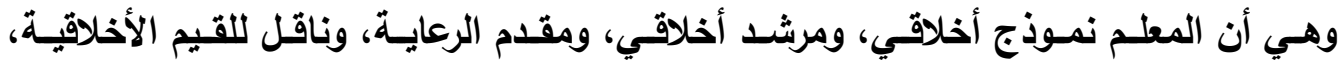
وميسر، ومستشار، ومحاور.

ويمكن تطبيق الوسطية الإسلامية من خلال أُسلوب التربية بالقدوة الحسنة فيما يأتي:

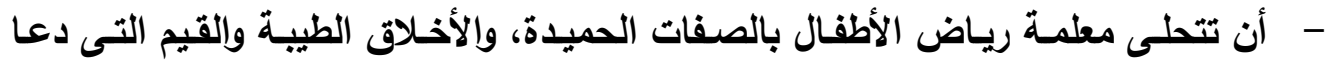

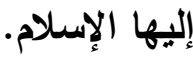

- أن تلتزم بالمظهر اللائق من حيث نظافة الملبس، وأن تكون ملابسـها ملائمة ومعتدلة بحيث لا تكون ضيقة أو شفافة أو قصيرة، وتلتزم بتقليم الأظافر ، وعدم التبرج. - ألا تتلفظ بألفاظ بذيئة وغير لائقة أمام الأطفال. - - ألا تكون كثيرة المزاح، ولا عبوسة الوجه وإنما معتدلة تتسم بالثخصية المتزنة بـلا إفراط ولا تفريط. - - أن تكون عادلة وموضوعية وتراعي الفروق الفردية بين الأطفال. - - أن تتصف بالصبر والحكمة والرحمة والثفقة بالأطفال وتحسن معاملتهم. • أُسلوب الحواروالإقتناع: يعد الحوار وسيلة المعلم والمتعلم للتعبير عن وجهات نظرهم وآرائهم وإيصال مقترحاتهم بهرف إيجاد فهم مشترك وتحقيق الفائدة المرجوة، فالحوار من أنجح وأفضل الأسـاليب التريوية التـي تقوم على الإيجابيـة والوديـة بين المعلم والمتعلم، فالحوار مهم في غرس الثقة بـين الأطفال وتثجيعهم على الاستقلالية وتحمل المسئولية واتخاذ القرارات، وتزداد الحاجة للحوار البناء لمواجهة التحديات القائمة في العصر الحالي حيث يتعرض الطفل لسيل من المعلومـات

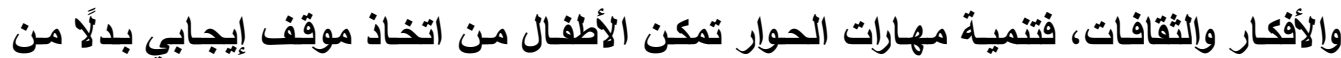

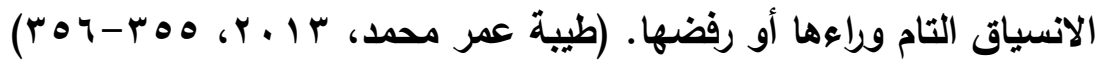
كمـا أن التربيـة عـن طريـق الحـوار مـن أفضـل الأســاليب التريويـة لأن الطفـل يقتــع بالمعلومـات والأفكار المراد إكسـابها لـه بطريقة مناسبة من خـلال الحوار التربوي بعيدًا عن أساليب التربية التقليدية القائمة على التلقين والحفظ، كما أن الحوار يربي في الطفل مهارات التفكير المختلفة والنقد البناء، كما يعود الطقل آداب التحدث والاستماع والحوار. 
وأكدت دراسـة (Peter Teo, 2019) على أن التعلم القائم على الحوار والتدريس الحواري من متطلبات القرن الحادي والعشرين، وهذا يتطلب من المعلمين أن يزودوا الطلاب بتعليم شـامل يركز على المهارات الحياتيـة مثل التواصل، والتعـاون بين الثقافـات، والتفكير النقدي، والإبـداع، فالتربيـة الحواريـة تسـعى إلسى تسـهيل بنـاء الطـلاب للمعرفـة مسن خـلال الاستجواب وإلتفاوض على الأفكار والآراء والاحترام المتبادل. ويمكن تطبيق الوسطية الإسلامية من خلال أُسلوب الحوار فيما ئأتي: - - أن يتسم الحوار بالاحترام المتبادل بين المعلمة والأطفال. - - أن يتميز الحوار بالمرونة وتقبل الرأي والرأي الأخر دون التعصب للأرأي. - أن يكون الحوار في جو هادئ بعيدًا عن التعبب والانحياز والصوت المرتفع. - - احترام كل آراء الأطفال وتعزيز ثقتهم بأنفسهم، وتعديل الآراء الخاطئة أو المغلوطة. - - مراعاة الفروق الفردية بين الأطفال حتي يحقق الحوار أهدافه التريوية.

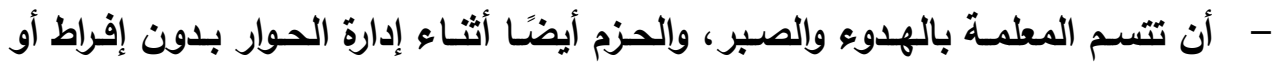

$$
\text { تفريط. }
$$

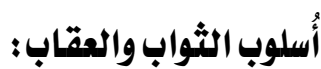

يستخدم الثواب والعقاب كآلية لترسيخ القيم أو إحلال قيم جديدة محل قيم أخرى غير

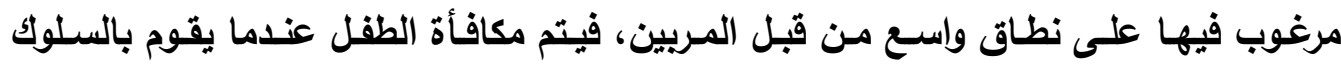
المرغوب فيه كأداء الأمانة أو التعاون مع الأصدقاء أو المشاركة في بعض الأعمال المنزلية، ويُعاقب الطفل إذا لم يفعل ذلك. ويؤكد المنهج التربوي الإسـلامي على ضرورة التوازن بين الثواب والعقاب في تربيـة الطفل والاعتدال في التعامل معه فـلا إفراط ولا تفريط، كمـا يعتبر المنهج التربوي أن العقوية النفسية هي عقوية مؤئرة وقوية ومن الممكن أن تؤدي إلى تغيير السلوك الخـاطئ للطفل، فإقنـاع الطقل بأن سلوكه السـوك الخـاطئ سـوف يؤدي إلى فقدانـه

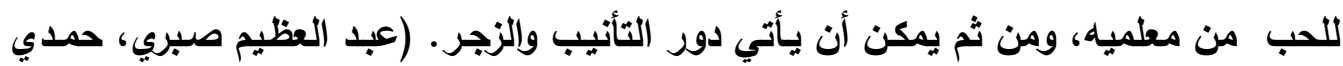

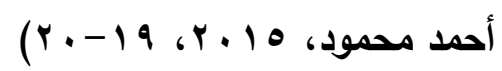

فقد أكدت دراسـة (Jitka Jakesov, Silvie Slezakova, 2016) حول المكافآت والعقويات في تعليم أطفال ما قبل المدرسة، على أن التعلم القائم على المكافآت أعطى نتائج أفضل من التعلم القائم على العقويات، فالمكافآت أدت إلى تثجيع التعلم، بمـا في ذلك التعلم 
الاجتماعي الذي له أثر كبير في التعليم بعكس العقويات التي لا يمكن للمري أن يتوقعها والتي

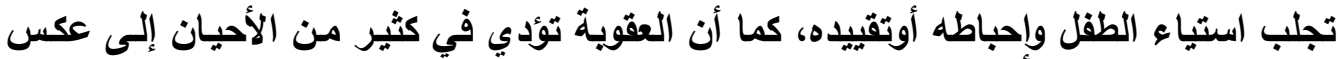

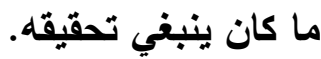
ويمكن تطبيق الوسطية الإسلامية من خلال أُسلوب الثواب وإلعقاب فيما يأتي: - الموازنة في استخدام أُسلوب الثواب والعقاب في العطلية التربوية. - - عدم الإفراط والإسراف في استخدام الثواب أو العقاب في تربية الطقل.

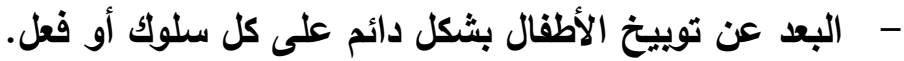

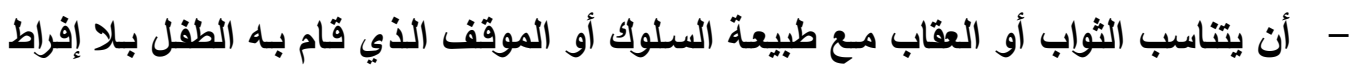
ولا تفريط.

- استخدام الحكمة عند تطبيق هذا الأُسلوب حتى لا يفق الهذف منه.

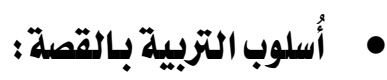
تعد القصة من الأساليب الحايثة في تنشئة الطفل وتربيته ولها قدرة على جذب انتباه

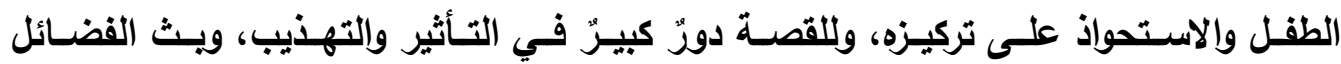
والأخلاق الحميدة دون الحاجة إلى العظة المباثرة، وهي تستهوي الطفل منذ طفولته المبكرة

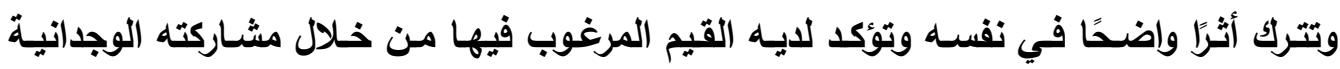

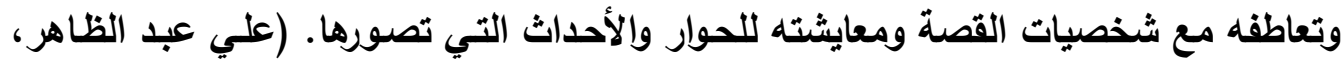
$(1 \cdot-9, r+1 V$ كما تلعب القصص والحكايات دورًا مهمًا في التربيـة الأخلاقية للأطفال، وتلهم الأطفال

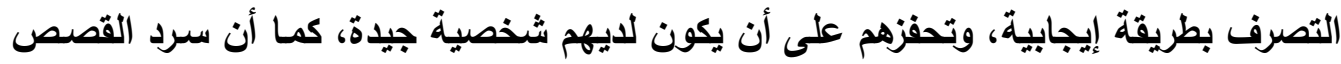

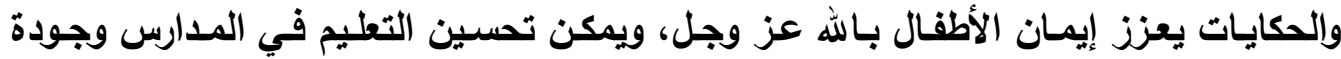
التربية الأخلاقية من خلال استخدام سرد القصص والحكايات. Others, 2017, 301 (Maila Dinia Husni Rahiem فالقصة في الأصل هي منهج رياني، حيث يزخر القرآن الكريم بالقصص، كقصص

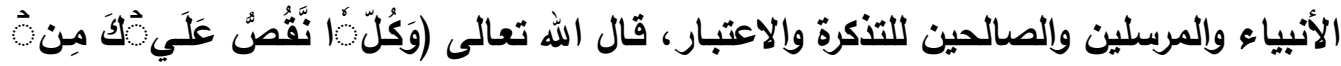

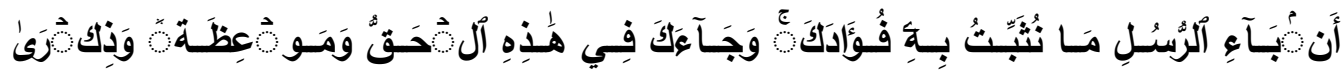

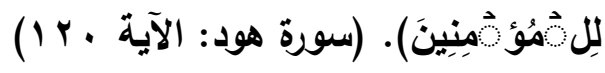


ويمكن تطبيق الوسطبة الإسلامبة من خلال أُسلوب القصة فيما بأتي:

- - اختيار القصص التي تحمل معاني الوسطية وتدعو لها وسردها للأطفال. - - التركيز على القصص النبوي وقصص الأنبياء والمرسلين والصحابة والتابعين. - - اختيار القصص التي تدعو إلى البعد عن التطرف والانحراف لأنه سبب المشكلات. - استبعاد قصص الرذائل، وقصص الرعب، وقصص الخيال الجامح المبالغ فيه التي تصيب الطقل بالإحباط، والقصص التي لا فائدة لها. - عدم سرد القصص التي ثُقفد الطقل القدوة، والقصص غير التريوية والتي تؤئز سلبًا على عقول ونفوس الأطفال كقصص الثخصيات الكارتونية سبايدرمان، وياتمان، وسويرمان،

$$
\text { وغيرها. }
$$

- البعد عن القصص التي تغرس في نفوس الطقل القيم السلبية كالعنف والأنانية، والسلوكيات السيئة كالعناد والسرقة والكذب، والتركيز على تلك التي تتؤكد على قيم الوسطية التي يدعو إليها الإسلام كالتسامح والتراحم والإيثار والصدق والعدل والإخوة.

$$
7 \text { ـ دور معلمة رياض الأطفال في تطبيق الوسطية ؛ }
$$

تعد معلمة رياض الأطفال هي حجر الأساس في العملية التريوية وأهم عناصرها، فهي تتؤدي دورًا مهمًا في تربية الأطفال، وغرس أسس ومبادئ العقيدة، وثوابت الدين الإسـلاهي، وهي المسئولة عن غرس القيم والسلوكيات الصحيحة في نفوس الأطفال، وتحصين الأطفال ووقايتهم من الانحراف والتطرف، وتلعب دورًا مهمًا في تكوين وغرس الوسطية الإسـلامية لدى طقل الروضة.

ويمكن تحديـد بعض أدوار معلمـة ريـاض الأطفـال في تطبيـق الوسـية في ريـاض الأطفال فيما يأتي: - أن تتسم معلمة رياض الأطفال بشخصية وسطية معتدلة متزنة بعيدة عن التشدد والتعصب بلا إفراط ولا تفريط. - أن تكون على قدر كبير من الهاوء واللين في معاملة الأطفال، رحيمة بهم محبة لهم عطوفة وتحترم جميع الأطفال. - - أن تتمتع بشخصية مرنة، وتعطي بعض الحريات للأطفال وتشجعهم على التعبير عن آرائهم بموضوعية ويدون خوف. 
- أن تتميز بالأمانة العلمية والفكرية القائمة على الوسطية، وأن تكون أمينة في أداء رسالتها التريوية.

- أن تستخدم أساليب الحوار والمناقشة والإقتاع بلاًا عن التلقين والإجبار وفرض الرأي والأوامر والنواهي.

- - أن تهئ البيئة التريوية الديمقراطية المشجعة على الإبداع والابتكار وإلنقد البناء. - أن تكون قدوة حسنة وصالحة للأطفال قولًا وعملًا وسلوكًا، وخاصة أنها الماعة المربية

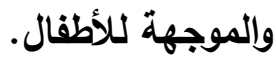
- أن تحرص على توعية الأطفال وتوجيههم إلى الخير وإكسابهم القيم الفاضلة والأخلاق الحميدة. - أن تصحح السلوكيات الخاطئة لدى الأطفال، والمظاهر السلوكية والقيم السيئة وتعدل أفكارهم بما يحقق أهداف التربية السليمة.

- أن ترسخ في نفوس الأطفال المفهوم الصحيح للوسطية، ونبذ التطرف والعنف والغلو. - أن تكون موجهة ومرشدة للأطفال من خلال إرشادهم للخير وإكسابهم الفضائل الأخلاقية، وتحذيرهم من الثر بكل صوره.

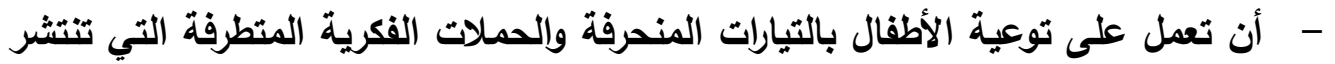
في العالم، والتي تسبب الكوارث والمشكلات والحروب نتيجة بعدها عن وسطية الإسلام. - أن تكسب الأطفال وتدريهم على مهارات التفكير العلمي الناقد وعدم التقليد دون فهم، والتمييز بين ماهو نافع وما هو ضار.

خاتهة:

في ضـوء مـا تـم عرضـه مـن خـلال محساور البحـث، توصلت الباحثّة إلـى أن التربيـة الوسطية التي لا تميل إلى الإفراط أو التفريط هي التربية المتوازنـة المعتدلة التي تبني جيلًا صـالحًا يطبق مـنهج الوسـية في كل حياتـه، وتعمـل على تحقيق أمسن واستـقرار وسـعادة المجتمع وتماسك أفراده. ولقد قامت الباحثة بعرض أهم مـا توصلت إليه من نتائج في ثنايا هذا البحث ويعض التوصيات لتربية طقل الروضة على الوسطية في الإسلام، وذلك على النحو التالي: 


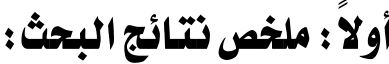

\section{استخلصت الباحثة بعض النتائج منها ما بلي:}

- إن الالتزام بمنهج الوسطية في التربية يحقق الخير للفرد والمجتمع، ويساعد في القضاء على التطرف بكل أنواعه. المتوازنة المعتلة التي تبني جيلاً صالحًا يطبق منهج الوسطية في كل حياته. - أكد البحث على أن التربية الوسطية هي منهج حياة كامل ينطبق على جميع جوانبها، وأن البعد عن الوسطية سبب كل المشكلات. - - أن التربية الوسطية يجب أن تُغرس وتُرسخ من بداية الطفولة حتى تؤتي ثمارها

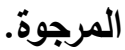

- أكد البحث على أهمية مؤسسات رياض الأطفال ودورها الخطير الذي تلعبه لتعزيز

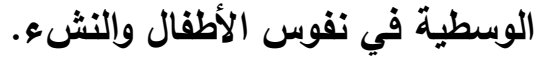
- أكل البحث على أهمية التربية في غرس وتعزيز الوسطية في نفوس الأطفال، وأن الوسطية قيمة حضارية وإنسانية تحقق السعادة والأمن لكل المجتمعات. - - أكد البحث على ضرورة تربية الأطفال على الوسطية الإسلامية، وغرس التربية الإيمانية الصحيحية لتحصينهم من الأفكار المنطرفة والمنحرفة. - أكد البحث على ضرورة تربية الأطفال وإكسابهم مهارات التفكير النقدي والعلمي والموضوعي، وعدم التقليد بدون وعي أو فهر. - أظهر البحث أهمية دور معلمة رياض الأطفال في ترسيخ الوسطية الإسلامية، وتقويم سلوكيات الأطفال غير الصحيحة كالعنف والعدوان. 
ثانيًا : التوصيات :

- ضرورة تفعيل دور رياض الأطفال كمؤسسة تريوية في غرس منهج الوسطية ومواجهة الغلو وإلتطرف وجطله من ضمن أهم أهدافها.

- - تربية الأطفال التربية الوسطية الرشيدة البعيدة عن التطرف والتلو من خلال ترسيخ ثقافة قبول الأخر وحسن التعايش معه. - عل دورات تدريبية لمعلمات رياض الأطفال لترسيخ مبدأ الوسطية في نفوس الأطفال ونبذ التطرف والغلو الديني. - - ضرورة تضمين برامج ومناهج وأنثطة رياض الأطفال لمبدأ الوسطية وآليات تعزيزها لاى طقل الروضة. - الإعلاء من قيمة الحوار في العملية التريوية برياض الأطفال. - - ضرورة الأخذ بمبادئ التربية الإسلامية وتطبيق الوسطية؛ لبناء شخصية الطقل المتزنة في جميع جوانبها دون إفراط أو تفريط. - - - إكساب الأطفال آداب الحديث والاستماع. - تربية الأطفال على مهارات التفكير الناقد وعدم التقلي بدون وعي وفهم وتفكير.

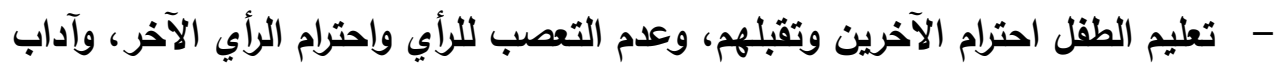
الاختلاف معهم وأن الاختلاف لا يفسد العلاقات الطيبة بين الناس. - - تربية الأطفال على منهج الوسطية الإسلامية لبناء شخصية الطفل المتوازنة في جميع جوانبها، وغرس الفضائل الأخلاقية والقيم الإسلامية. - - غرس القيم والأخلاق الإسلامية في نفوس الأطفال كقيم التسامح، والرحمة، والإيثار، واحترام الآخرين، والتواضع. - - نشر الوعي الصحيح بالوسطية من خلال كل مناشط رياض الأطفال ويرامجها، وخطورة التشدد والثلو على المجتمع. - تعزيز قيم الوسطية لاى معلمات، ومديرات رياض الأطفال وكل القائمين على العملية التريوية بالروضة من خلال عقد الندوات وعمل اللقاءات والمؤتمرات لاعم الوسطية لدئية

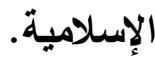




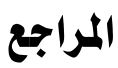

أولًا : المراجع العربية والمصادر:

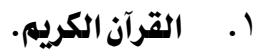

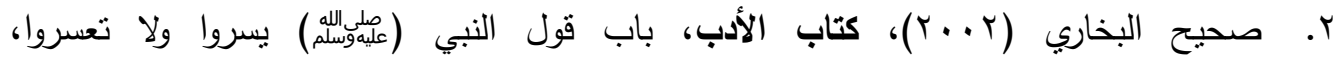

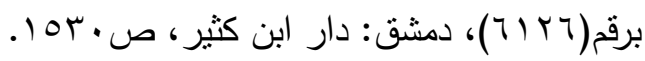

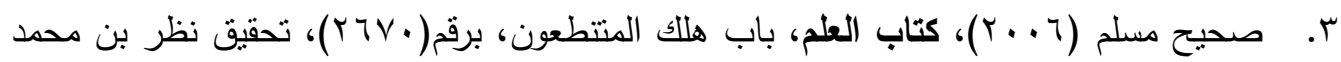

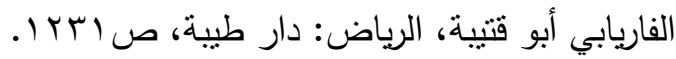

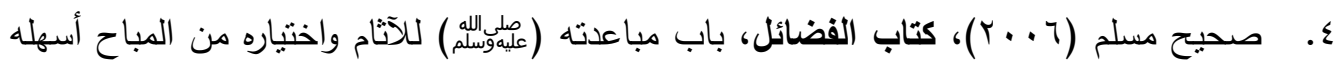

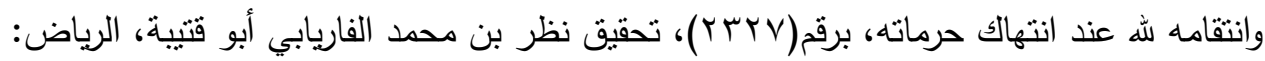

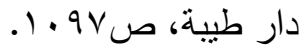

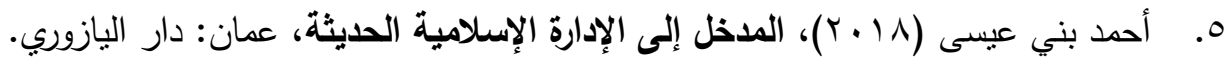

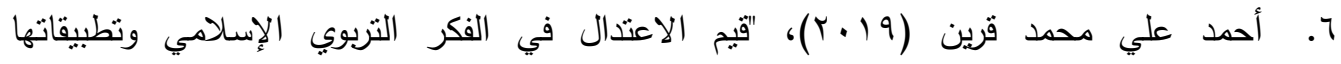
المعاصرة"، رسالة دكتوراه، كلية التربيه، جامعة سوهاج.

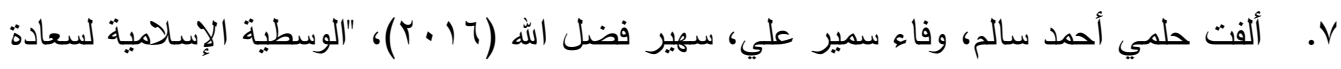

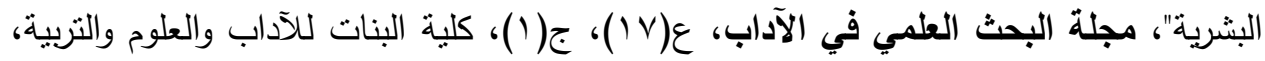
جامعة عين شمس، ص ص .10-1791.

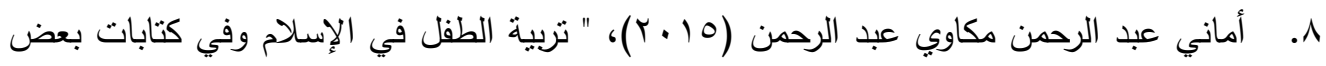

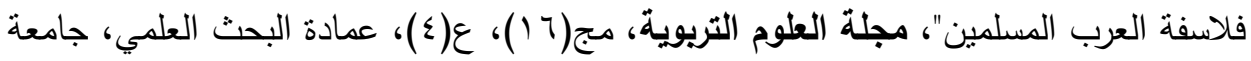
السودان للعلوم والتكنولوجيا، ديسمبر ، ص ص هب إ- . ع أ. 9. آمنه حسين عبد المولى بركات (10 • ب)، "تزبية الطفل في الإسلام"، مجلة العلوم القانونية

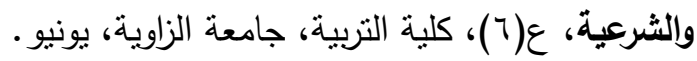

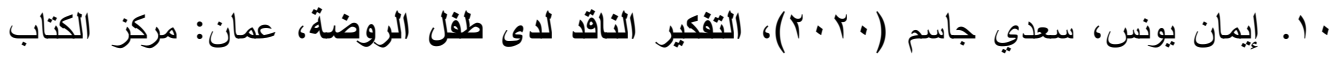
الأكاديمي.

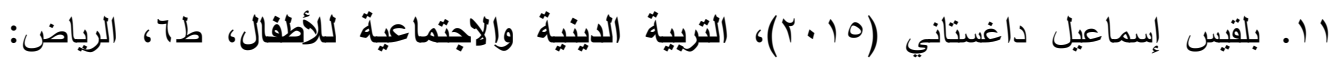

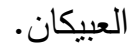

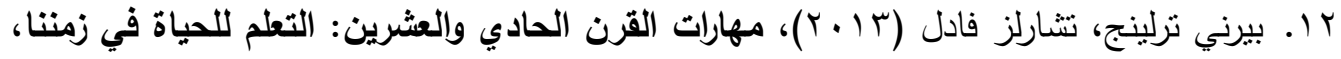
ترجمة بدر بن عبد اله الصالح، الرياض: مكتبة الملك فهد. 


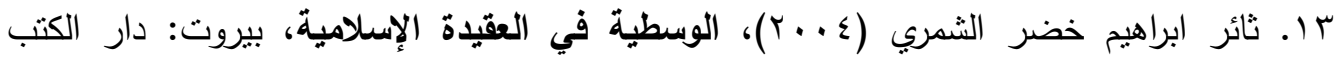
العلمية.

ع ا. ـ خالد بن حامد الحازمي ( . . ب)، أصول التربية الإسلامية، المدينة المنورة: عالم الكتب.

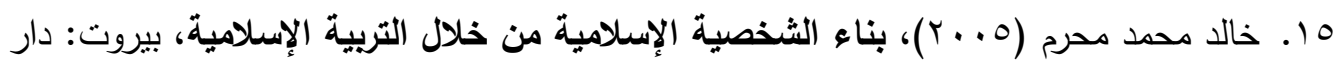
الكتب العلمية.

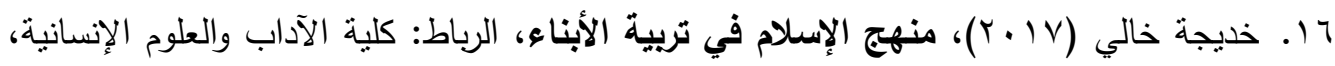
جامعة محمد الخامس.

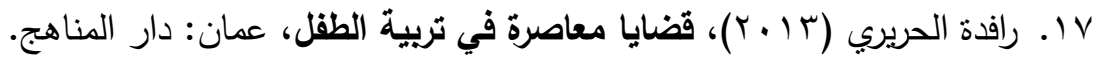

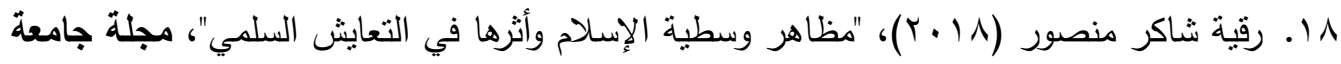

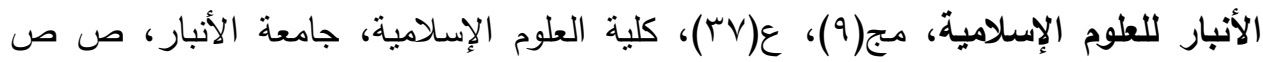

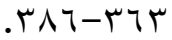

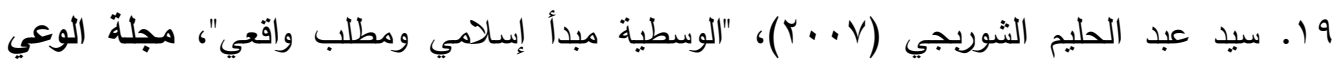
الإسلادي، ع(0.0)، الكويت: وزارة الأوقاف والثئون الإسلامية.

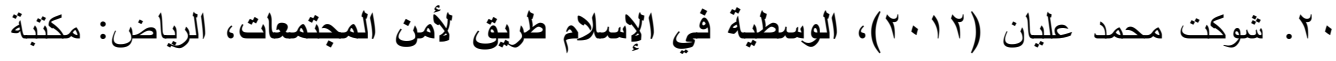
الملك فهر الوطنية. اY.

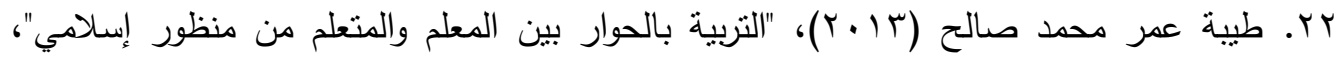

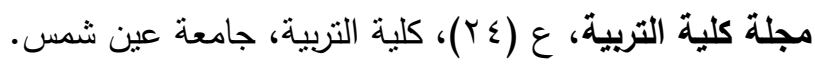

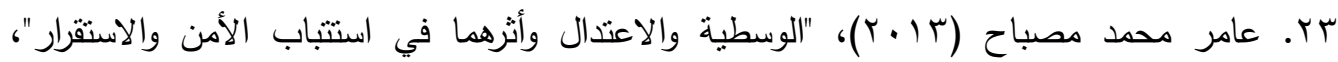
المؤتمر العلمي العربي السادس: التعليم وآفاق ما بعد ثورات الربيع العربي، الجمعية المصرية

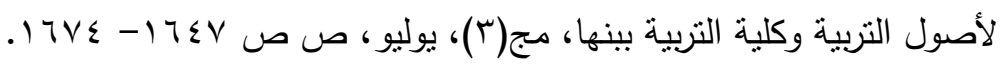

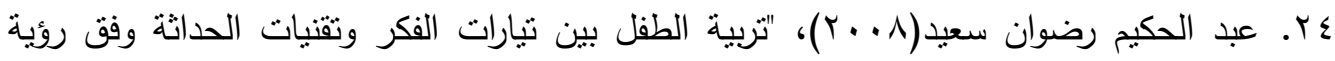

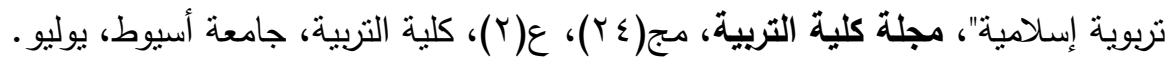

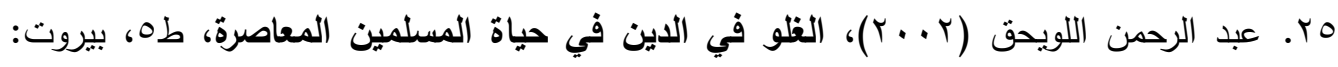
مؤسسة الرسالة. Tr. عبد الرحمن الهانشي، أحمد ابراهيم صومان، محمد ابراهيم الخطيب، فايزة محمد فخري

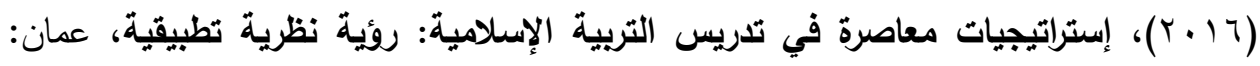




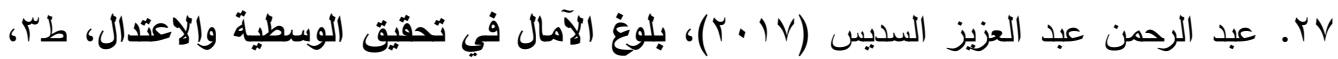
الرياض: مدار الوطن.

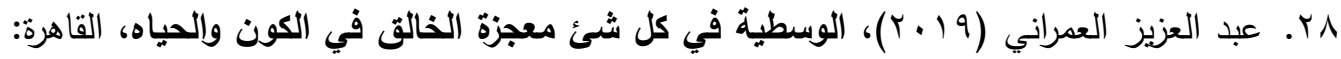
دار الأمة.

q. الصغير، القاهرة: المجموعة العربية.

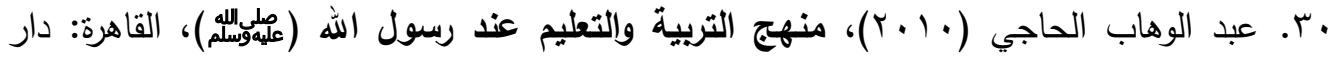
الكتب العلمية.

اس. عدنان مصطفى إبراهيم خطاطبة (Y (Y))، "دور المنهج الوسطي التزبوي في الإسلام في تكوين

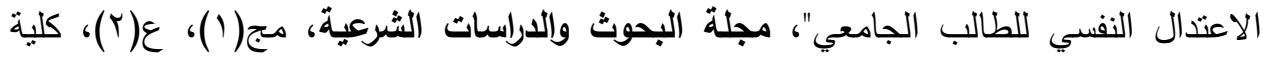

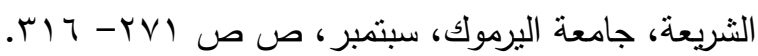

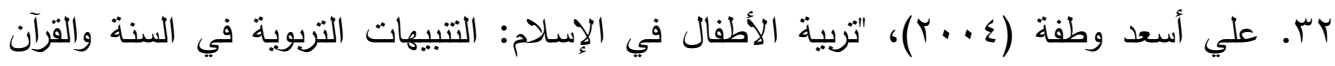

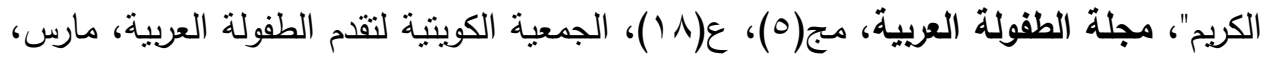

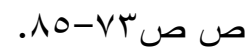

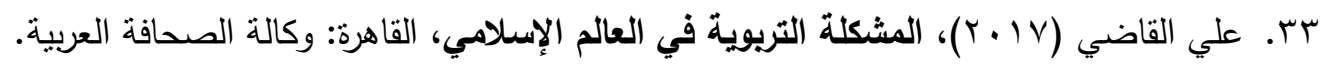

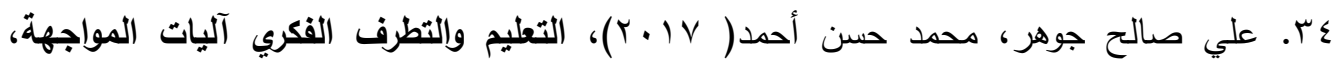
المنصورة: المكتبة العصرية.

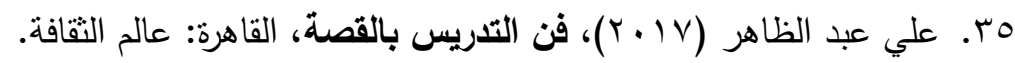

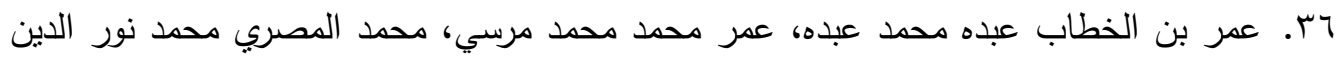

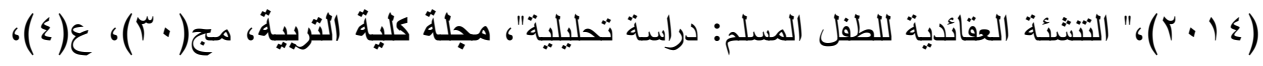
كلية التربية، جامعة أسيوط.

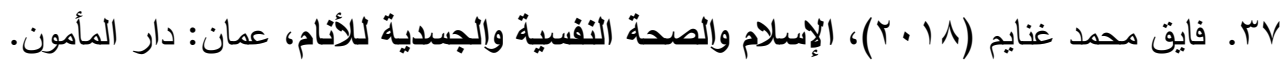

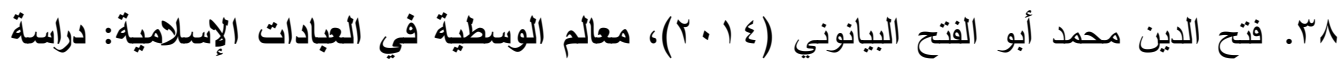
تحليلية في ضوء السنة النبوية، الرياض: كرسي الأمير سلطان بن عبد العزيز للاراسات الإسلامية المعاصرة.

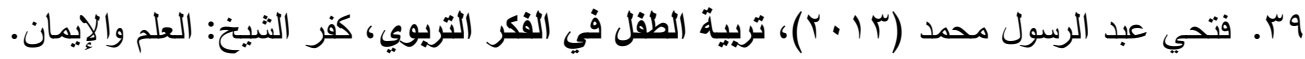

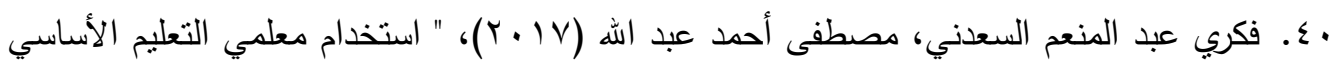
لأساليب التربية العقدية لمواجهة النطرف والإرهاب: دراسة ميدانية"، المجلة الدولية للعلوم 
التريوية والنفسية، ع(0)، المؤسسة العربية للبحث العلمي والتتمية البشرية، فبراير، ص ص ب ا.70

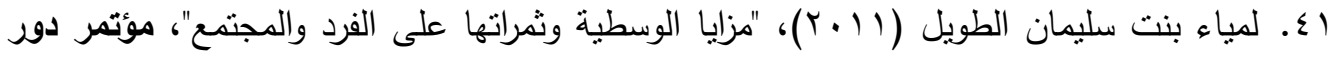

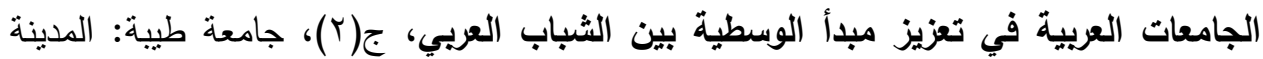

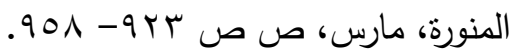

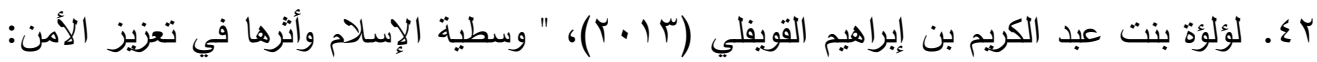

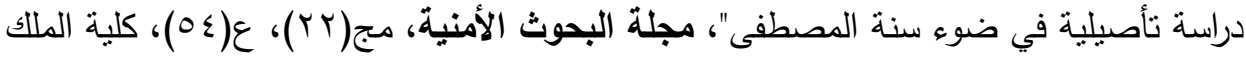

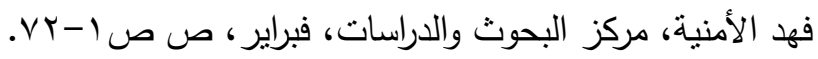

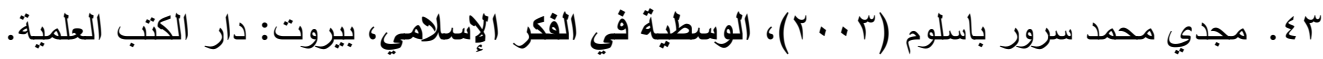

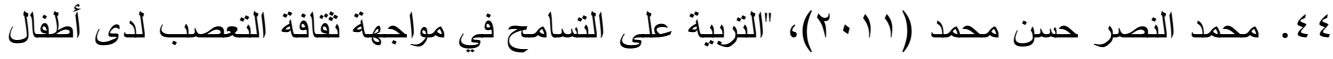
جنوب الصعيد في مصر"، مجلة الثقافة والتتمية، ع(0؛)، جمعية الثقافة من أجل الثتمية

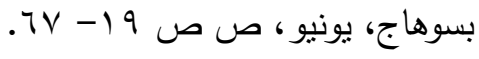

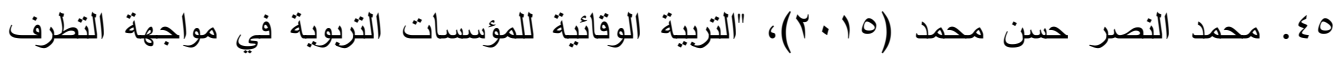

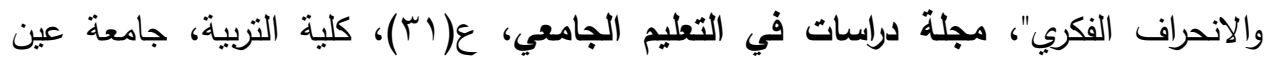

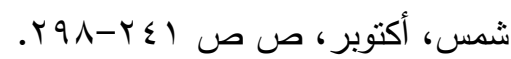

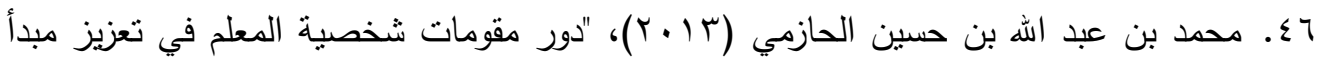

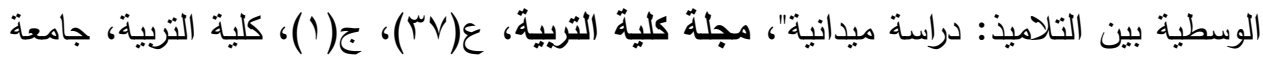

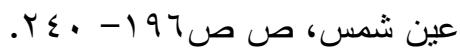

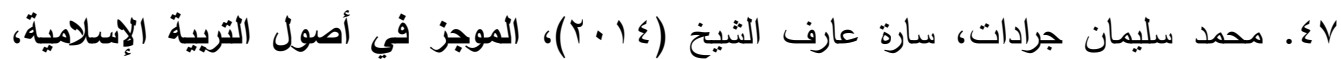
عمان: دار الخليج.

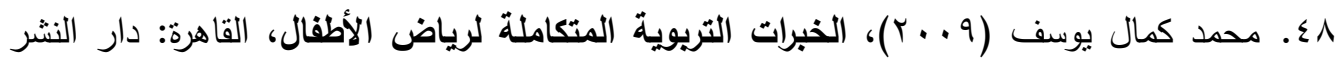
للجامعات.

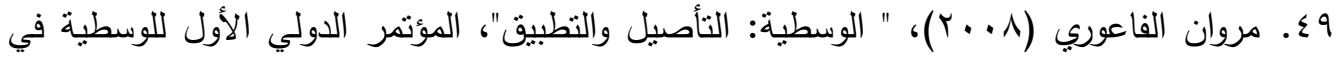
لبنان "، المؤتمر الدولي الأول للوسطية في لبنان المعنون بـ " الوسطية: مشروع الإنسانية

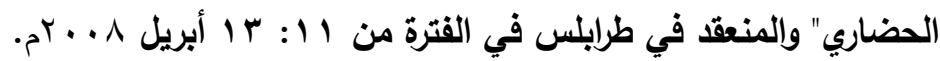

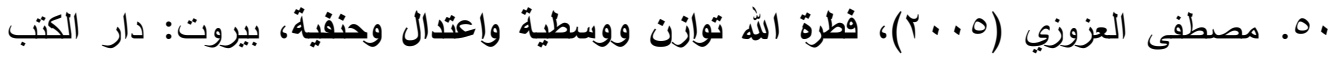
العلمية. 


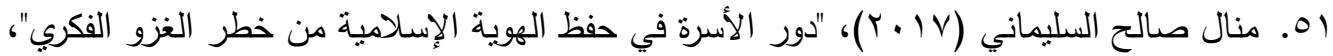

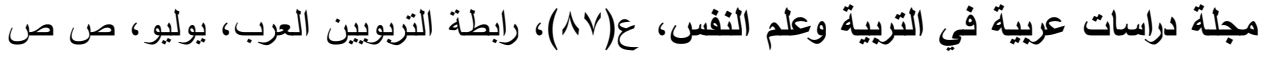
$.0 \cdot 0-\varepsilon V V$

Yo. منى أحمد الأزهري، منى سامح أبو هشيمة، التربية الحركية لطقل ما قبل المدرسة، القاهرة:

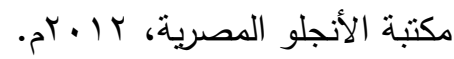

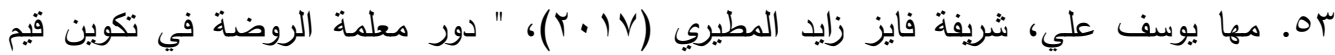
الوسطية والاعتدال الديني لاى طفل الروضة بدولة الكويت في ضوء المتغيرات المجتمعية

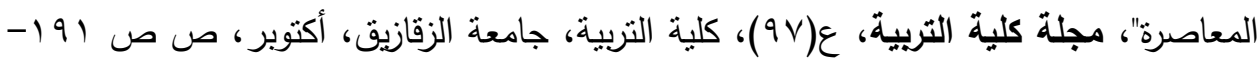
. TY.

ـه. مؤسسة الباحث للاستشارات البحثية بالقاهرة (19 ـr)، التربية الإسلامية أسس بناء وتربية

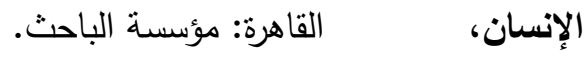

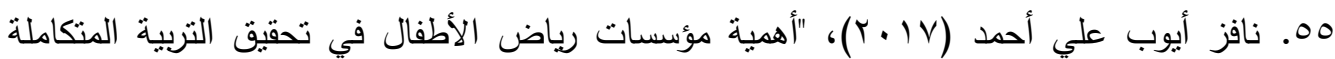

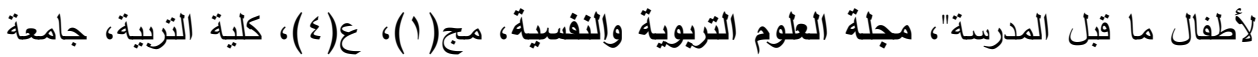

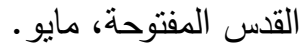

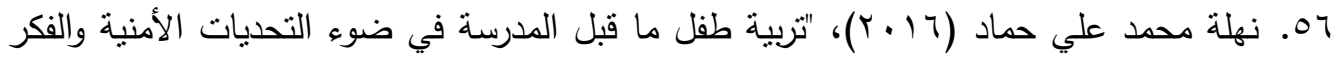

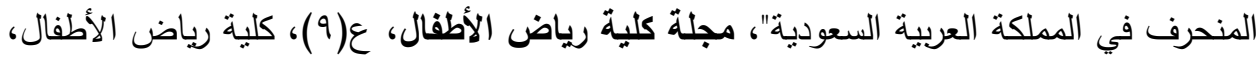

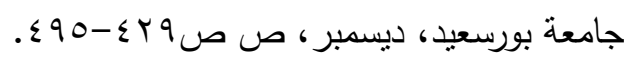

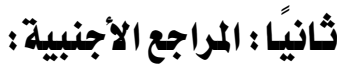

57. Elisa Kupers, Andreas Lehmann, Gary McPherson \& Paul van Geert (2019), "Children's Creativity: A Theoretical Framework and Systematic Review", Review of Educational Research, Vol (89), No(1), February.

58. Heli Muhonen, Eija Pakarinen, Marja-Kristiina Lerkkanen \& Lydia Barza (2020), "Patterns of dialogic teaching in kindergarten classrooms of Finland and the United Arab Emirates", Learning, Culture and Social Interaction, Vol (25), December, pp 67-79.

59. Jitka Jakesova, Silvie Slezakovab (2016), "Rewards and punishments in the education of preschool children", Social and Behavioral Sciences, Vol (217), pp 322 - 328.

60. Maila Dinia Husni Rahiem, Nur Surayyah Madhubala Abdullah \& Steven Eric Krauss (2017), "Kindergarten Teachers and Moral Education for Young Children: Why Do Narratives Matter?", Advances in Social Science, Education and Humanities Research (ASSEHR), Vol(58). 
تربية الأطفال على الوسطية في الإسلام ...

61. Maizura Yasin, Nur Surayyah Madhubala Abdullah \& Norzihani Saharuddin (2020), "Roles of Teacher and Challenges in Developing Students' Morality", Universal Journal of Educational Research Vol(8), January, pp 52-59

62. Michael J. Baker (2020), "Types of types of educational dialogue", Learning, Culture and Social Interaction, February, 100387, article In press.

63. Molly Efrat (2015), “"I found it! I found it!" Achild's chance discovery as a basis for learning using the kindergarten multi-dialogical approach", Social and Behavioral Sciences, Vol (209), July.

64. Nicole Leggett (2017), "Early Childhood Creativity: Challenging Educators in Their Role to Intentionally Develop Creative Thinking in Children", early childhood education journal, Vol (45), January.

65. Peter Teo (2019), " Teaching for the 21st century: A case for dialogic pedagogy", Learning, Culture and Social Interaction, Vol (21), March, pp $170-178$. 